Article

\title{
University 4.0: Promoting the Transformation of Higher Education Institutions toward Sustainable Development
}

\author{
Bror Giesenbauer * (D) and Georg Müller-Christ \\ Faculty of Business Studies and Economics: Sustainable Management, University of Bremen, \\ Enrique-Schmidt-Str. 1, 28359 Bremen, Germany; gmc@uni-bremen.de \\ * Correspondence: giesenbauer@uni-bremen.de
}

Received: 17 February 2020; Accepted: 16 April 2020; Published: 21 April 2020

check for updates

\begin{abstract}
Higher education institutions (HEIs) could act as pivotal change agents for sustainable development (SD) in times of global climate action. However, HEIs have to respond to increasingly complex demands simultaneously, such as massification, globalization, marketization, and digitalization. Based on Graves' model of systemic development, this paper discusses two main strategies to deal with increased complexity in order to meet the challenge of SD: (a) Promoting general systemic development of a given HEI, progressively opening up to various stakeholders and focusing on co-creative collaboration, and (b) participating in inter-organizational networks to find inspiration for dealing with challenging trends. Four distinct phases of higher education development are presented. It is argued that transdisciplinary research and research-based learning will increasingly be needed for tackling societal issues and that HEIs should address different organizational subsystems individually. Furthermore, four types of inter-organizational networks are proposed and implications for network management are discussed. A case study of the HOCH-N network illustrates the practical application of the presented ideas. Finally, adopting a multi-dimensional and networked organizational model as an integrative University 4.0 is argued to be suitable for increasing the capacity to deal with complexity, thus meeting the challenge of sustainable development.
\end{abstract}

Keywords: higher education development; sustainable university development; systemic development; inter-organizational networks; sustainable development; worldviews; societal transformation; systemic transformation

\section{Introduction}

In times of climate change and massive societal change, universities and other higher education institutions (HEIs) are called to become change agents for societal transformation [1]. However, HEIs are facing complex times, juggling very disparate roles and demands [2]. From educating increasing numbers of students to conducting internationally competitive research, from acquiring grants and even making profits to serving society, from managing large physical campuses to integrating digitalization, from serving the local while keeping an eye on the global, and from supporting excellence in research in disciplinary niches to championing interdisciplinary topics such as sustainable development (SD): HEIs have to react to global trends that are difficult to chase at the same time and that indeed often impose conflicting goals. As the success of HEIs is mostly measured by international rankings and leadership in specialized disciplines, the advancement of cross-cutting topics such as sustainable development is often compromised [3].

Being part of the German research consortium on 'Sustainability at Higher Education Institutions' (Nachhaltigkeit an Hochschulen) HOCH-N [4], we wondered how HEIs could possibly come to integrate 
the pressing challenge of SD into their actions while also having to manage the aforementioned challenges. Two blog articles by Massachusetts Institute of Technology (MIT) scientist and consultant Otto Scharmer on the systemic development of HEIs toward SD sparked our interest and seemed promising [5,6]. Therein, Scharmer proposes that HEIs should focus on "systemic upgrades" and increased inter-organizational collaboration in order to be able to deal with the challenge of SD. However, as the intersection between HEI development and SD is a relatively new one, the underlying systemic framework of Scharmer's articles has not yet been linked to sustainable higher education development in a scientific context.

The main research question we set out to answer is therefore: (A) Which general systemic strategies would help HEIs to deal with the complex challenges of the 21st century in order to live up to the challenge of sustainable development? Two secondary research questions were derived from our practical application of the presented ideas in the HOCH-N project: (B1) How can models of systemic development be applied to the development of HEIs? (B2) How can inter-organizational networks contribute to the integration of SD into HEIs and to the general systemic development of HEIs?

Having a background in the research on corporate sustainability management and systemic development in particular, we chose to focus our research on conceptually applying scientific models of systemic development that have proven to be of value to the analysis of corporate sustainability to the field of HEI development and SD and that seem to inform Scharmer's ideas scientifically. It is our understanding that all sound empirical research needs to be built on sound conceptual models and sound operationalization thereof. Thus, this contribution is intended to advance theory building on the transformation of higher education by systematically applying Clare W. Graves' model of systemic evolution to sustainable higher education development. This novel conception of higher education development will help to differentiate existing broader conceptions (cf. [7-9]), like the idea of a continuum of sustainability governance by Niedlich et al. [9].

As the overarching theme of this paper is the transformation of HEIs toward meeting the challenges of sustainable development, the latter is shortly introduced in Section 2.1. In order to set the stage for introducing two systemic strategies for managing complexity at HEIs, an encompassing theoretical framework is introduced in Section 2.2 and later applied to the advancement of sustainable development in higher education: Clare W. Graves' $[10,11]$ theory of systemic evolution, originally derived from empirical data in the 1950s and 1960s [12]. Four distinct developmental phases of worldviews are presented and applied to HEIs in Section 3 (answering research question A and B1) and to inter-organizational networks in Section 4 (answering research question B2). The latter application is illustrated with examples from the German network for sustainability at HEIs "HOCH-N". Finally, the role of networks in promoting systemic change is discussed and further implications for change agents are inferred.

Thus, based on our practical work and the ideas of Scharmer [5,6], this paper introduces two strategies of how HEIs and their members are managing the complex demands of the 21st century: the first strategy is to promote the transformation of higher education in general, resulting in HEIs that are able to handle more complexity, requiring an update of a given HEI's self-concept and worldview (see Section 3). This strategy will lead to a multi-dimensional and networked organizational model, described as HEI 4.0 or University 4.0. The second, more specialized strategy is to engage in inter-organizational networks in order to connect with members of other HEIs dealing with similar challenges (see Section 4). The second strategy is essentially already implied by the first strategy. Conversely, the purpose of networks is often to nudge systemic transformation.

A case study of the German HOCH-N network is included in order to illustrate the proposed ideas on network management (Section 4.2). This case study focuses on the key structures, services, and products of the HOCH-N network, linking them to the presented systemic ideas on network management. It is not intended to "prove" the preceding conceptual framework as case studies are not suited to falsify conceptualizations in a classic way. However, the main scientific contribution of a case study can be described as "case-inspired self-reflection" [13] (p. 347) (cf. [14]). In this sense, the case 
study on $\mathrm{HOCH}-\mathrm{N}$ is intended to illustrate the practical application of the systemic theories at hand, to validate their subjective usefulness, and to inspire ideas for application in the reader.

Combining Graves' theory with the development of higher education and inter-organizational networks is the main contribution of this paper to the existing body of research, substantiating the ideas of Otto Scharmer on sustainable higher education development. It is further intended clarify the role of networks in promoting the systemic change of HEIs toward SD.

\section{Background: The Challenge of Sustainable Development and Systemic Development}

How can higher education institutions (HEIs) live up to the challenge of sustainable development (SD) while also having to deal with complex issues such as internationalization, massification, or marketization [2,15]? Following the reasoning of Otto Scharmer, HEIs would need to upgrade their "operating system" (cf. [6]) and increase their network activities in order to integrate SD as a whole-institutional approach $[5,6]$. But what is meant by sustainable development in higher education? And how can the upgrading of a HEI's operating system be understood?

In the following section, the topic of sustainable development is thus shortly introduced and linked to HEIs. Thereafter follows an overview of Clare W. Graves' systemic theories which have been applied successfully to the field of corporate sustainability and are linked to managing increasingly complex challenges $[16,17]$. Section 2 closes with a reflection of principles of systemic development to countervail the popular misconception that systemic development models are overly deterministic and judgmental models (see e.g., [18]).

\subsection{Sustainable Development in Higher Education}

Education for sustainable development has become increasingly important for HEIs and societies in general during the past three decades and thus, has created a more complex environment for operating a HEI. While this paper deals specifically with the challenge of integrating sustainable development (SD) into HEIs, the issue of SD is also used to illustrate complex systemic demands in general.

The publication of "Our Common Future" in 1987 by the world commission on environment and development [19] promoted the term "sustainable development" and gave birth to large global efforts to spread and develop the concept. Therein, SD is defined as "development that meets the needs of the present without compromising the ability of future generations to meet their own needs." [19] (p. 41). From the mid-1990s on, researchers have conceptualized ways of implementing SD both as a concept and as a way of thinking at universities (see e.g., $[1,20]$ ). Since then, the research on universities' role in supporting sustainable development has matured, especially in the context of competencies for future challenges (see e.g., [21-23]).

In September 2015, the United Nations [24] General Assembly adopted the Agenda 2030 resolution and thereby amplified the commitment to SD with the 17 sustainable development goals (SDGs) [25]. This framework aids in breaking down the complexity of SD into more practicable fields of action. Education for sustainable development (ESD) is part of SDG 4: High quality education.

Along those developments, the cause of sustainable development has received widespread attention and a lot of effort has been put into promoting it at higher education institutions [26,27]. In particular, the adoption of the SDGs and an increasing societal awareness of climate change urges HEIs to integrate SD into their actions.

But even though the idea of sustainability has reached the general public-for example, through Greta Thunberg and the Fridays for Future movement- the concept of sustainability itself has not yet made it to mainstream academia $[8,28,29]$. For example, the SDGs are rarely integrated into existing curricula or campus operations at German HEIs in spite of the fact that Germany has strong political initiatives for SD and ESD such as the German Council for Sustainable Development of the German Federal Government (Rat für Nachhaltige Entwicklung), the German Advisory Council on Global Change (WGBU), and the German National Action Plan for ESD (Nationaler Aktionsplan BNE) [30]. Moreover, the term sustainability is subject to several misconceptions which impedes the advancement of SD at HEIs [31]. 
One of the reasons that SD has not made its way into mainstream academia and management of HEIs is likely to be found in its inherent complexity, as SD requires systemic transformation and not only adaptation $[7,32]$. In other words, taking the challenge of SD seriously will lead to more tensions and dilemmas and therefore, to increased complexity [33]. Consequently, Bauer et al. [7] argue that HEIs should implement SD as a whole-institution approach in order to encourage transformative practices at all levels. If a given HEI wants to get serious about integrating the idea of sustainability, it should therefore aim to build its capacity to deal with complexity and ambiguity and lean into a more integrative worldview, which will be explained and discussed below.

\subsection{Theoretical Background: Worldviews and Systemic Development}

To understand complex systems such as universities and the field of higher education in general, it is helpful to build on a framework that is able to structure and explain the evolution of systems in general-the "upgrading of operating systems", as Scharmer coins it (cf. [6]). The psychologist Clare W. Graves developed such a systemic theory from the 1950s to the 1970s, trying to explain adult human development based on his own empirical data [10-12]. Graves distinguished eight distinct worldviews, also described as value systems, phases, or levels, and later, a ninth worldview was proposed. His teachings were made popular in the 1990s by his followers Don Beck and Christopher Cowan under the name of Spiral Dynamics [10]. In this paper, we rely mostly on the adaptations by the Dutch researchers Annick Hedlund-de Witt [34-36] and Marcel van Marrewijk [37,38], as well as on our own works $[3,16,17,30,39]$ and on a few popular science works that shed light on practical nuances of the model $[5,6,10,40,41]$.

According to Graves, the development of systems and adults oscillates between worldviews that focus on the individual and worldviews that focus on the collective $[10,38]$. In simplified terms, whenever societies or smaller groups start focusing almost exclusively on the needs of the collective while suppressing individual interests, individuals tend to fight for their right of self-expression. This will usually lead to more individual freedom which in turn can develop into an exaggerated individualism and a loss of social cohesion, resulting in a renewed call for more considerate behavior and a stronger focus on the needs of the group [10].

This oscillation between the collective and the individual in reaction to environmental challenges is described as an upward spiral development, similar to the double-helix model of DNA [11]. The idea of a spiral development also implies that certain phases or worldviews cannot be skipped-they have to be run through sequentially, though different speeds and depths of development are possible. For example, universities are expected to start from a solid infrastructure and orderly formal settings for teaching and studying, to then go on to building capacities for high quality research and only later to champion transdisciplinary research focusing on solving relevant societal problems. However, when new institutions are founded, they can of course build on the lessons from older institutions and speed their own development-especially compared to the systemic development of universities that were founded in medieval times with a focus on dissemination of factual knowledge.

\subsubsection{Four Worldviews: From Traditional to Integrative}

Not all of the worldviews or phases of Graves' model are relevant for the discussion of this paper. Following the reasoning of Hedlund-de Witt [35], only four worldviews from Graves' model will be discussed in detail as the preceding three worldviews are more applicable to e.g., tribes, early empires, and mafia-type organizational forms and later worldviews are currently mostly expressed by individuals or in spiritual contexts. The four worldviews in question can theoretically be applied to the development of both individuals, organizations, and societies as a whole. They are, therefore, first introduced in general terms before being applied to the development of HEIs in particular (Section 3) and to different types of inter-organizational networks (Section 4). Table 1 contrasts the four relevant worldviews with respect to their central values and foreshadows their application to HEIs and SD. 
Table 1. Overview of four different worldviews ${ }^{1}$.

\begin{tabular}{|c|c|c|c|c|}
\hline & Traditional Worldview & Modern Worldview & Postmodern Worldview & Integrative Worldview \\
\hline $\begin{array}{l}\text { guiding principles and values; } \\
\text { keywords }\end{array}$ & $\begin{array}{l}\text { order; security; absolute truths; } \\
\text { correctness }\end{array}$ & $\begin{array}{l}\text { success; goals; optimization; } \\
\text { professionalism; materialism; efficiency; } \\
\text { finding good deals }\end{array}$ & $\begin{array}{l}\text { taking care; inclusion; community; } \\
\text { individual expression; humanism; } \\
\text { awareness; responsibility }\end{array}$ & $\begin{array}{l}\text { finding non-dogmatic solutions; } \\
\text { effectivity; relativity; acting in spite of } \\
\text { complexity and tensions }\end{array}$ \\
\hline purpose/self-concept & $\begin{array}{l}\text { creating structure in a chaotic } \\
\text { world }\end{array}$ & $\begin{array}{l}\text { optimizing an overly rigid world; } \\
\text { designing a functional world }\end{array}$ & $\begin{array}{l}\text { slowing down an exploitative world; } \\
\text { creating safe spaces }\end{array}$ & $\begin{array}{l}\text { mending a broken world; } \\
\text { integrating all levels }\end{array}$ \\
\hline common societal examples & $\begin{array}{l}\text { bureaucracy; formalized } \\
\text { religion; classic family-owned } \\
\text { corporations }\end{array}$ & $\begin{array}{l}\text { shareholder owned corporations; } \\
\text { evidence-based medicine }\end{array}$ & $\begin{array}{c}\text { NGOs; stakeholder-oriented } \\
\text { organizations (esp. employees and } \\
\text { customers) }\end{array}$ & $\begin{array}{l}\text { purpose-driven organizations; } \\
\text { self-managed teams }\end{array}$ \\
\hline basis for solutions & $\begin{array}{l}\text { authority (moral, legal, or } \\
\text { patriarchal); rules; goodwill }\end{array}$ & $\begin{array}{l}\text { optimal allocation of resources; process } \\
\text { analysis; competition; calculations }\end{array}$ & $\begin{array}{l}\text { collaboration; common ground; } \\
\text { community; purpose }\end{array}$ & $\begin{array}{l}\text { competence; synergy; } \\
\text { co-creation; purpose }\end{array}$ \\
\hline possible negative expression & $\begin{array}{l}\text { unfair; bureaucratic; ideologist; } \\
\text { unengaged individuals }\end{array}$ & $\begin{array}{l}\text { too egocentric; disrupting cooperation by } \\
\text { competing; lost in detail; too } \\
\text { opportunistic }\end{array}$ & $\begin{array}{l}\text { ineffective; overly political correct; } \\
\text { complacent; allowing only certain aspects } \\
\text { of individual expression }\end{array}$ & $\begin{array}{l}\text { too unbound and detached; not } \\
\text { empathetic; arrogant }\end{array}$ \\
\hline $\begin{array}{l}\text { typical topics related to } \\
\text { sustainable development }\end{array}$ & $\begin{array}{l}\text { waste management; hygiene } \\
\text { and basic health; basic } \\
\text { infrastructure; public policies; } \\
\text { understanding and } \\
\text { documenting changes in } \\
\text { ecosystems; nature protection }\end{array}$ & $\begin{array}{l}\text { resource efficiency and efficient resource } \\
\text { allocation; green tech; renewable energies; } \\
\text { health; modeling future scenarios }\end{array}$ & $\begin{array}{l}\text { education for sustainable development; } \\
\text { externalities; health; agriculture; } \\
\text { sustainable economic processes } \\
\text { (production and consumption); peace }\end{array}$ & $\begin{array}{l}\text { systems transformation; climate change; } \\
\text { green infrastructure; spirituality; } \\
\text { enabling and sustaining capacity to act in } \\
\text { times of complexity; co-creative } \\
\text { democracy }\end{array}$ \\
\hline prototypical scientist & objective observer & $\begin{array}{l}\text { professional, objective user of } \\
\text { scientific method }\end{array}$ & $\begin{array}{l}\text { developer of new methods; hearing the } \\
\text { unheard; highlighting pressing global } \\
\text { problems }\end{array}$ & $\begin{array}{l}\text { co-creator and broker of effective } \\
\text { methods and solutions }\end{array}$ \\
\hline
\end{tabular}

${ }^{1}$ Based on $[12,16,36,38]$. 
The traditional worldview is marked by a focus on absolute truths, rule obedience, and a trust in authorities [38]. This kind of value system laid the foundation for very stable empires and organizations that were able to last for hundreds of years, e.g., the Catholic church and some universities like those located in Oxford, Salamanca, or Heidelberg. It is not by chance that these universities were indeed founded to disseminate absolute truths from a Christian perspective [42]. The traditional worldview enabled societies to adopt a long term perspective, going beyond patterns of instant gratification found in earlier empires, and thus gave birth to enormous projects such as the construction of the Gothic cathedrals that often took several hundred years to be finished. However, its focus on one right way and bureaucratic regulations makes the traditional worldview less able to deal with unplanned incidents and oftentimes prevents people from thinking on their own [10].

The modern worldview can be seen as a reaction to the inherent rigidity of the traditional worldview. Modern science, technology, and neoliberalism are expressions of this way of thinking, which highlights individual effort and the pursuit of success [3]. Indeed, the modern worldview has led to enormous breakthroughs for civilization [43], exemplified by the material wealth of industrial nations and the invention of airplanes, satellites, computers, and advanced medical treatments. However, the rise of the modern worldview has also brought about massive negative ecological and social side effects. When both people and the earth are merely seen as means to an end, ecological and social systems are often subject to abuse and deterioration.

The postmodern worldview can in turn be seen as a reaction to the side effects of phenomena such as neoliberalism, materialism, and consumerism and is often expressed in an attempt to go "back to the roots" and to find more "natural" solutions $[10,38]$. Trying to make minorities and underserved groups heard, postmodern activists will often take a critical stance toward neoclassical economics and quantitative science. More moderate and forgiving expressions of the postmodern worldview can be seen in the rise of team work and in the focus on customer and employee satisfaction [17]. This type of worldview has therefore brought about more humane, ecological, and considerate procedures and championed topics such as gender equality, diversity, and sustainability [38]. In general, it will favor community building over hierarchy and consensus over individual competence, sometimes leading to inefficient and even ineffective ways of responding to challenges.

Finally, one of the more current developments of society has brought about the integrative worldview (also called synergistic, integral, or systemic) [17,38,44]. The integrative worldview can be framed as a reaction to ever-increasing societal complexity: Issues such as globalization, global migration, and climate change challenge traditional ways of decision making and problem solving and highlight the interconnectedness of various systemic phenomena. As a consequence, individuals and organizations alike are often called to take action in spite of not being able to foresee the probable main and side effects of each action. A certain tolerance of ambiguity is therefore needed in order to maintain the ability to take action $[17,38]$. Consequently, the management of tensions has been made the center-piece of the integrative framework for corporate sustainability by Hahn et al. [45,46], which was recently applied to the development of HEIs by Annina Lattu and Yuzhuo Cai [33].

The historic breakthrough of the integrative worldview is thus the ability to see both the relative truths and pitfalls of each preceding worldview and therefore being able to act as a broker in times of extremism and societal separation [3,44,47]. Instead of taking a fixed position, the integrative worldview facilitates effective problem solving based on co-creative and competency based methods of innovation, thereby challenging conventional ways of operating businesses, politics, or HEIs [48]. However, when the integrative worldview is only developed in the cognitive line of development and does not include emotional development of the same magnitude, it might lack empathy and thus lead to aloofness and arrogance. Therefore, intention setting and mindfulness are important parts of integrative practices, shifting the focus from "ego" to "eco", as Otto Scharmer puts it [41] (cf. p. 3).

While the descriptions above seem to imply a hierarchy of development and therefore dismiss the modern and especially the traditional worldview, all worldviews are inherently equally important. However, they can be more or less suited to handle different environmental conditions. Furthermore, 
worldviews are often combined and can be temporarily adopted depending on the situational context. As these finer points are important for the application of the model, various systemic principles are compiled in the following section.

\subsubsection{Principles of Systemic Development}

Before the four worldviews are applied to HEIs and inter-organizational networks, we would like to highlight a couple of important principles of systemic development to provide a more differentiated view and to countervail possible misconceptions.

1. Each subsequent worldview is able to handle more complexity than the preceding ones [11]. Worldviews are adapted to changes in the system's environments. When a system is facing increasingly complex challenges, as HEIs currently do, an upward movement to a more complex worldview might be needed to effectively deal with the novel threats and demands.

2. No worldview is inherently "better" than another-different worldviews are simply more or less suited to handle environmental conditions [3]. More complex worldviews enable individuals and organizations to deal with more complexity-which can sometimes be "better", as stated above. However, a person just coming from drug rehabilitation might, for example, require a setting with a more structured and rule-focused worldview (traditionalist worldview) in order to tame a chaotic life and might actually be overwhelmed with the requirements of self-management (integrative worldview). Similarly, a country without a stable educational system might first need to implement more traditionalist forms of education before it starts implementing more integrative practices.

3. Subsequent worldviews transcend and include preceding ones [38,40]. For the sake of simplicity, each worldview is illustrated by its prototypical and novel characteristics. However, the lessons and principles from preceding worldviews are not annihilated. For example, when societies moved from more hierarchical and feudalistic structures (pre-traditionalist and traditionalist worldview) to more fluid capitalist democracies (modern worldview), the use of common rules was not suspended but merely reframed: rules were still regarded as important, but more as means to an end (like material success) than as ends in themselves.

4. Worldviews might be dominant but not necessarily exclusive [16]. Certain worldviews are often conjoined. For example, leaders of multinational corporations often follow strict metric-based strategies of profit maximization (modern worldview) while promoting team work and focusing on customer-satisfaction on a more operative level (postmodern worldview). Likewise, HEIs can simultaneously be places of more traditionalist teaching (e.g., massive lectures in general undergraduate education) and both modern and postmodern research practices (e.g., stakeholder-oriented mixed-methods approaches).

5. Systems are made of subsystems [16]. Organizations are in effect stratified and usually include several worldviews at once [49]. In HEIs, technical, administrative, and scientific staff tend to have their own distinct (world-)view on things. While a more traditionalist rule-focused worldview often suits administrative work, scientists might often gravitate more toward process optimization with regards to their career (modern worldview) and toward a stakeholder-perspective with regards to their students (postmodern worldview). However, the integrative worldview is the first one to not only be aware of different worldviews, but to explicitly acknowledge their respective strengths and shortcomings.

6. Worldviews can be adopted temporarily $[10,40]$. While each individual, subsystem, and system is usually centered around one or two dominant worldviews, other worldviews can temporarily become dominant. Indeed, it is common to operate from different worldviews or states of consciousness in different contexts-for example, when talking to a police officer, attending a sport event, making a sales call, or during meditation. 
7. Development can go both ways [10]. When being confronted with changed environmental conditions and threats, systems might react by opening up and embracing complexity or by shutting down and regressing to a perceived "tried-and-true" way. The latter is illustrated by the rise of populistic political parties in Western societies in the face of globalization.

8. A novel worldview will usually contest its predecessor. When a certain worldview is emerging, its proponents will, from our observations, usually focus on the shortcomings of the preceding worldview to underline why the novel one is more suited to the current environmental conditions. However, both worldviews might later be reconciled and form a functional alliance. As an example, the postmodern worldview found an early expression in a certain kind of environmentalism that not only highlighted the negative side effects of modern market economies (modern worldview), but that also rejected business endeavors in general; whereas today, both worldviews are often combined in ideas such as social entrepreneurship.

These principles are important to keep in mind because models of systemic development are otherwise too easily misinterpreted as judgmental models, separating "the highly evolved" from "the primitive". On the contrary, each worldview represents an important contribution to the development of individuals and societies. The main question is, therefore, not "Which worldview is better?", but "Which feature of which worldview is best suited for the current environmental conditions?".

\section{Systemic Development of Higher Education Institutions}

As pointed out in the introduction, HEIs and especially research universities are placed under tremendous pressure by a variety of societal trends, creating an environment of enormous complexity [50]. Following the rationale of systemic development and Clare W. Graves' $[10,11,51]$ assumptions, this should lead to minor and major updates to the prototypical worldview of a given HEI. In order to deal with the increasing complexity, HEIs are likely to adopt more and more postmodern and integrative values and practices. But what does that mean for the character of a HEI? In the following, four types of worldviews in the systemic development of HEIs are shortly introduced, following the ideas of Georg Müller-Christ [39], Otto Scharmer [5,6], and Bror Giesenbauer and Merle Tegeler [3]. As these four HEI specific worldviews have historically evolved in a sequential manner, they are also described as phases of HEI development. Furthermore, as these phases can be described as major upgrades to the "operating system" of a HEI [5], they are labelled with numbering from 1.0 to 4.0, following the nomenclature of software development. When abstracted from their historic occurrence and translated into a conception of sustainability governance, they can be framed as representing four distinct conditions along the continuum of sustainability governance proposed by Niedlich et al. [9].

The major characteristics of each phase of HEI development are summarized in Table 2 and described in Section 3.1-with a focus on the conception of an integrative HEI or University 4.0, which is argued to be needed in times of complexity. Section 3.2 will then explore implications for management of sustainable higher education development based on the presented phases of HEI development in Section 3.1 and the principles of systemic development laid out in Section 2.2.2. In order to make these theoretical implications more tangible, Section 3.2.1 provides examples for the central fields of education, research, and governance. 
Table 2. Four phases of higher education institution (HEI) development from a worldview perspective. ${ }^{1}$

\begin{tabular}{|c|c|c|c|c|}
\hline & Traditional HEI 1.0 & Modern HEI 2.0 & Postmodern HEI 3.0 & Integrative HEI 4.0 \\
\hline general focus on & - input, authority and hierarchy & - output, efficiency and competition & $\begin{array}{l}\text { - dialogue with stakeholders } \\
\text { and learners }\end{array}$ & $\begin{array}{l}\text { - } \quad \text { systemic solutions, co-creativity } \\
\text { and sustainability }\end{array}$ \\
\hline education & $\begin{array}{l}\text { - } \quad \text { teacher-centric; } \\
\text { - } \quad \text { me scientist reads his books; } \\
\text { standardizized knowledge; } \\
\text { - learning for recognition and } \\
\text { academic titles }\end{array}$ & $\begin{array}{l}\text { - } \quad \text { test-centric; } \\
\text { disseminating factual knowledge, } \\
\text { analytic strategies and } \\
\text { sound methods; } \\
\text { - } \quad \text { modules and projects; } \\
\text { - learning for the test; } \\
\text { - learning as a competitive game for } \\
\text { future success }\end{array}$ & $\begin{array}{ll}\text { - } & \text { learner-centric; } \\
\text { - } & \text { competencies-oriented transfer of } \\
\text { - } & \text { folf-reflective knowledge; } \\
\text { - } & \text { project-based learning; } \\
\text { - } & \text { blended learning; } \\
\text { - } & \text { learning as personal growth }\end{array}$ & $\begin{array}{l}\text { - } \quad \text { system-centric, holistic; } \\
\text { - } \quad \text { dynole-person approach; } \\
\text { matter, group, individual learners } \\
\text { and context; } \\
\text { - } \quad \text { research-based learning; } \\
\text { - co-creative and mindful learning }\end{array}$ \\
\hline research & $\begin{array}{l}\text { - } \quad \text { search for absolute truths; } \\
\text { self-concept: observing universal } \\
\text { natural laws; } \\
\text { - focus on strong theories based on } \\
\text { both deduction and induction; } \\
\text { - construction of disciplines }\end{array}$ & $\begin{array}{l}\text { - } \quad \text { standardization of research; } \\
\text { processes and peer-review } \\
\text { - } \quad \text { self-concept: testing and applying } \\
\text { natural laws; } \\
\text { - } \quad \text { competition for grants; } \\
\text { - } \quad \text { measurement of success with } \\
\text { rankings, impact factors etc.; } \\
\text { - } \quad \text { focus on quantitative methods }\end{array}$ & $\begin{array}{ll}\text { - } & \text { inter- and transdisciplinarity; } \\
\text { - } & \text { action research; } \\
\text { - } & \text { self-concept: understanding } \\
\text { - } & \text { dialogical research processes } \\
& \text { dealing with societal issues; } \\
\text { - } & \text { integration of qualitative } \\
& \text { research methods }\end{array}$ & $\begin{array}{l}\text { - } \quad \text { transdisciplinarity; } \\
\text { - } \quad \text { co-creative research; } \\
\text { - } \quad \text { syste-concept: co-creating } \\
\text { - } \quad \text { global action universation; } \\
\text { - } \quad \text { living lab approach; } \\
\text { - } \quad \text { focus on real-life solutions; } \\
\text { - } \quad \text { idea of open science }\end{array}$ \\
\hline $\begin{array}{c}\text { governance, } \\
\text { operations and } \\
\text { culture }\end{array}$ & $\begin{array}{l}\text { - focused on teaching, basic research } \\
\text { and technological transfer; } \\
\text { building palaces of knowledge: } \\
\text { impressive buildings and } \\
\text { extensive libraries; } \\
\text { - legitimacy by authority; } \\
\text { - compliant to regulation, e.g. waste } \\
\text { management and safety; } \\
\text { - one-dimensional approach } \\
\text { to sustainability }\end{array}$ & $\begin{array}{l}\text { - } \quad \text { focused on quantitative growth; } \\
\text { - } \quad \text { rapid growth in functional buildings } \\
\text { - } \quad \text { control of cash flows and } \\
\text { process management; } \\
\text { - } \quad \text { entrepreneurial activity; } \\
\text { - } \quad \text { science parks; } \\
\text { - sustainable development as a } \\
\text { management task }\end{array}$ & $\begin{array}{l}\text { - HEI as a place for meeting diverse } \\
\text { - } \quad \text { yet like-minded people; } \\
\text { facilitating community and } \\
\text { individual expression; } \\
\text { - } \quad \text { diversity management; } \\
\text { - } \quad \text { legitimacy by participation; } \\
\text { - } \quad \text { soal of climate neutrality; } \\
\text { communite development as a } \\
\text { mission content }\end{array}$ & $\begin{array}{l}\text { - HEI as a space for encounter, } \\
\text { reflection and inspiration; } \\
\text { physical and virtual integration of } \\
\text { different societal and } \\
\text { ecological systems; } \\
\text { - } \quad \text { whole-institution approach } \\
\text { to sustainability; } \\
\text { - additional fourth mission: } \\
\text { co-creation for sustainability }\end{array}$ \\
\hline
\end{tabular}

${ }^{1}$ Based on [3,5,6,9,39]. 


\subsection{Four Phases of HEI Development and Their Respective Worldviews}

Traditional HEI 1.0. Universities were historically invented from the catholic idea of preserving and teaching universal truths in medieval times [42], which can be framed as an expression of the traditionalist worldview. A supposedly "all-knowing" scholar dressed in academic gown would then read his teachings to relatively passive students, separated by strong disciplines. The impressiveness of large classicist university buildings as palaces of knowledge reflects this kind of focus on authority, stability, and persisting truths [39]. The prototypical HEI 1.0 might seem outdated and yet has succeeded in preserving academic education for several centuries. Indeed, its worldview still influences the ethos of modern universities-based on the systemic principle of transcend and include (see Section 2.2.2). By itself, a traditional HEI or University 1.0 is not likely to integrate fast-paced societal change and address cross-cutting topics such as sustainable development (SD) as a whole as these topics demand more openness, dialogue, and at least some degree of interdisciplinarity. However, even traditional universities had to adapt to societal change following the Age of Enlightment and the rise of modern democracy.

Modern HEI 2.0. Universities were reinvented in Germany in the $19^{\text {th }}$ century by Wilhelm von Humboldt and others as research universities [52], which were later adapted into the American model, combining the German research idea with the English collegiate tradition and the American idea of service to society [2] (cf. p. 8). As an early expression of the modern worldview (see Section 2.2.1), it focused on the research process, allowing for more fluidity and leading to the idea of continuous improvement and process optimization. The rise of the research university model enabled massive breakthroughs in terms of research methods, standards of publication, and historic innovations for civilization in fields such as technology, engineering, and medicine.

Current academia is mainly shaped by this reinvention of higher education in light of the modern worldview. Quantification, professional specialization, and competition form the basis for most endeavors of HEIs. HEIs 2.0 compete for grants, students, and placements in rankings and thus, in short, for quantitative success $[15,53]$. This orientation toward quantitative success is amplified by the trends of massification (as participation in higher education growths on national and international levels), globalization, and internationalization and leads to increased marketization and privatization [2,50]. Consequently, teaching has become test-centric and modularized and HEIs have come to adopt entrepreneurial activities. Furthermore, scientific careers can nearly exclusively be advanced within disciplinary niches based on metrics such as numbers of publications and impact factors, hindering the advancement of interdisciplinary fields and cross-cutting topics such as SD [3]. These trends seem to intensify at the moment even though there are parallel lines of developments.

Postmodern HEI 3.0. The main alternative development of higher education is currently shaped by the postmodern worldview, especially in the social sciences and humanities. Dismissing positivism and objectivism, the subjective viewpoints from both research participants and students stand at the center of research and education at postmodern HEIs. Seminars, project work, and qualitative research methods have been developed in the spirit of this HEI 3.0. Learning arrangements are then focused on competencies rather than on knowledge accumulation only [23]. Moreover, forerunners such as Kurt Lewin have introduced alternative approaches to research such as action research $[3,54]$. These developments occurred together with student movements from about the 1950s, protesting against patriarchal hierarchies of HEI 1.0 and the somewhat mechanical teaching styles of HEI 1.0 and 2.0. This type of postmodern HEI or University 3.0 has brought about a focus on societal issues such as SD and led to the rise of interdisciplinary research. Researchers operating from a postmodern worldview will usually try to make everyone heard and to include regional and international stakeholders [22]. However, researchers often have to play by the rules of the modern worldview of HEI 2.0 in order to advance their careers, leading to trade-offs and tensions on a personal level [3] (cf. p. 645).

Integrative HEI 4.0. As conventional ways of decision making and education (including postmodern dialogical practices) are put under pressure by increasingly fast-paced and complex societal changes in times of globalization and digitalization, some parts of HEIs have come to adopt novel practices in line with the integrative worldview. So far, there are few pure examples for these 
Universities or HEIs 4.0. However, experiences from smaller academic projects and other organizational forms (e.g., businesses) operating from an integrative worldview allow for preliminary descriptions of this emerging type of HEI.

Integrative HEIs 4.0 will likely exhibit a focus on self-management, a strive for wholeness, as well as an awareness of their evolutionary purpose, taking responsibility and trying to actively participate in societal change $[3,43]$. Taking systems as a whole into perspective, the co-creation of effective solutions for pressing societal issues such as SD will be emphasized in HEIs 4.0. Based on Graves' model of systemic development, HEIs or Universities 4.0 are bound to act as brokers for integrative processes, facilitating synergies between different societal sectors.

Building almost exclusively on Russian research and philosophical works, Alla Lapteva and Varlerii Efimov come to very similar conclusions and conceptualize a University 4.0 as "an infrastructure platform" for a variety of activities [55] (p. 2691). Focusing on the technical basis for HEI development, analogous to the waves of industrial revolution, Lapteva and Efimov stress the importance of telecommunication technologies for Universities 4.0. Consequently, HEIs and Universities 4.0 would be expressions of a "cognitive society" [55] (p. 2690), making use of hybrid technologies and collective intelligence [56]. HEIs become, in short, "a very open environment - a hub for a variety of communications, a node at the intersection of multiple networks ( ... ). These communications, research works and development projects involve not only professors and students, but also a wide range of external participants." [55] (p. 2691).

Consequently, new concepts for higher education such as the living lab approach [57] are built around the idea of inclusive and dynamic research processes (see Section 3.2.1). The inclusion of students and citizens in the research process is intended to facilitate deep learning and to link research with education, knowledge transfer, and real-life application [58]. And even without direct field testing of ideas, research-based learning and co-creative innovation methods can be applied in courses. At the very least, learners should be encouraged to personally engage with sustainability and to learn by experiencing and becoming aware, going beyond mere cognitive processing [59].

Emphasizing the transformative aspect of HEI development, Otto Scharmer and Katrin Kaufer propose that learning at integrative HEIs 4.0 will be shaped by action learning, global classrooms, innovation hubs, and individualized lifelong learning journeys [60]. Scharmer goes on to argue in two blog posts that the university of the 21st century should in essence focus on providing vertical development literacy, i.e., the ability to understand systems and their respective worldviews and to guide these systems through a systemic upgrade, if needed [6]. According to Scharmer, this leading of transformative change requires the skill of "deep listening", self-awareness, and compassion [5].

Similarly, Uwe Schneidewind [61] proposes that HEIs should focus on facilitating transformative literacy, i.e., the ability to understand and participate in social transformation, including the technological, economic, institutional, and cultural dimensions of transformation. Sustainable development will then supposedly not be a special topic to deal with, but an integral part of a HEIs' DNA and governance [3,62]. Interestingly, the qualitative data from a multi-case study by Niedlich et al. [9] suggest a linear relationship between the orientation toward organizational learning of a given HEI and the degree of holistic orientation of its sustainability governance, supporting the general assumption that the development of HEIs from 1.0 to 4.0 equals a general systemic upgrade, going beyond incremental and isolated updates.

\subsection{Leading Multi-Level Development of HEIs}

The presented four phases of systemic HEI development are intended to provide a map for navigating the transformation of HEIs in the 21st century. In times of increasing complexity and a "knowing-doing gap", as Scharmer [5] coins it, HEIs would do well to prepare for a systemic upgrade in order to keep up with societal demands, specifically the challenge of sustainable development. Currently HEIs around the world are at very different stages of development, described as stratification of higher education [63]. We would go one step further and argue that each HEI in itself is stratified as 
is, as different organizational subsystems emphasize different worldviews and exhibit different levels of maturity within a given worldview. Transformation would thus necessitate a consciously chosen multi-level approach.

However, this systemic upgrading is no easy task, especially with the principles of systemic development in mind (see Section 2.2.2). For example, how does one ensure and maintain the quality of teaching and testing while experimenting with new forms of education? How does one decide what to keep from the "old" system and how to transcend it in light of newly adopted core principles? And how should one address different subsystems of a given HEI? As these questions do not have a fixed answer, change agents might profit from engaging in peer networks (see Section 4).

At the very least, HEIs should practice self-reflection, open up to societal discourse, and prepare for necessary change, if judged to be appropriate. This includes that not all subsystems have to embrace complexity and transdisciplinary research. If, for example, a molecular biologist finds that robust quantitative methods (based on the idea of falsification and statistical inference) and exclusive discourse within their disciplinary niche are still the most fitting approaches, then change agents would do well to support them in continuing that type of research. At the same time, the communication of research results and processes might be adjusted by publishing in open access journals and including students in the research process to facilitate research-based learning. Similarly, research questions connected to hot topics such as climate change might be favored.

As most HEIs are expected to be centered around the traditional 1.0 or modern 2.0 worldviews, the next step would likely be one of strengthening the ideas of quality control (traditional worldview) and process optimization (modern worldview), while also championing dialogical forms of research and education (postmodern worldview). Inspiration for taking the predominant HEI 2.0 one step further can be found in J.G. Wissema's 3GU model [64], mainly with regards to restructuring HEIs-enabling more interdisciplinary research in institutes, professionalizing HEI management, and promoting entrepreneurial activities and outreach.

In sum, the integration of more participatory, open, and transdisciplinary practices should be encouraged at all levels while simultaneously consolidating methodological rigor and effective process management-rethinking prevalent ways of HEI organization. In this way, a University or HEI 4.0 will become an infrastructure platform for cross-sectoral communication, facilitating open science and co-creative problem solving.

\subsubsection{University 4.0 Practices for Education, Research, and Governance}

Even though the systemic development of a given HEI can hardly be prescribed generically, some examples for different fields of action might be helpful to inspire customized measures. Thus, we will present a couple of loosely chosen best practices for the areas of education, research, and governance.

Education. As HEIs will move toward a larger proportion of postmodern and integrative practices, education will likely be focused on a whole-person approach, developing (personal) competencies in co-creative settings, rather than on knowledge and methods only [65]. One didactic approach that has been proven vital for leading co-creative seminars with learning groups of all levels is Ruth Cohn's Theme-Centered Interaction (TCI). TCI offers a clear framework for dynamically balancing different factors of group learning - namely, the subject matter ("it") at hand, the needs of the group ("we"), the needs of each individual ("I"), as well as the demands of the specific context (the "globe") [66] (see Figure 1 for a display of the TCI model). Although it was originally developed for facilitating group therapy sessions, it has successfully been applied to classrooms in both primary, secondary, and higher education (see the work of Sylke Meyerhuber et al. [67] for its application to higher education). Its goal is to promote what Ruth Cohn called "living learning", a kind of learning which is based on the humanistic ideal of meeting the psychological needs of the group members in order to facilitate personal growth [66] (cf. p. 19). Living learning is further described as being "emancipatory in nature" and thus, supporting self-leadership; as viewing the group as a "source of learning"; as being led by teachers that are also co-learning; and as being oriented toward meaningful experiences 
and behavior [68] (p. 142). Due to its holistic nature, this approach seems well suited for facilitating transformative learning, especially education for sustainable development.

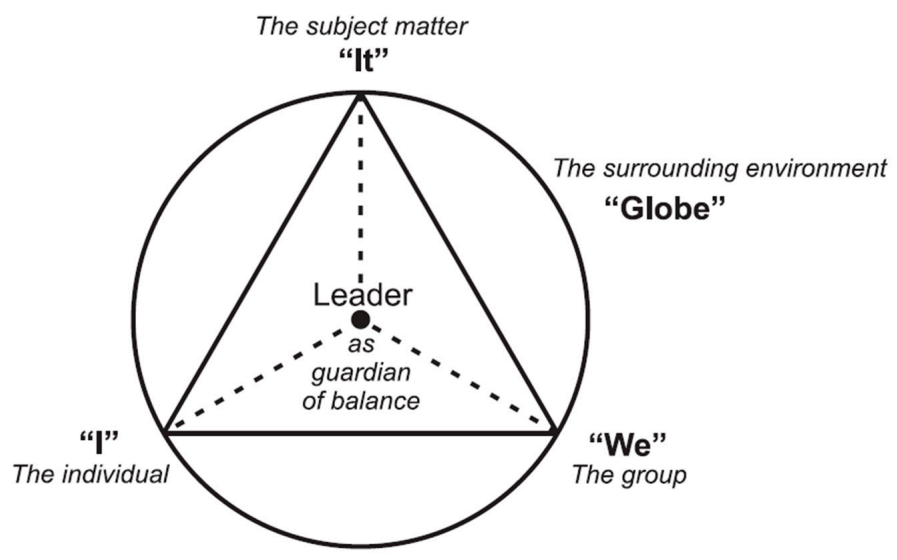

Figure 1. The four-factor model of Theme-Centered Interaction (TCI): group facilitation in dynamic balance (source: [66] p. 20).

From our experience, the Theme-Centered Interaction (TCI) approach is especially helpful for dealing with emerging topics and for integrating all kinds of disturbances (e.g., personal irritation, side talks, group conflicts, or arising needs) that would otherwise negatively impact the learning process [69]. Moreover, it accounts for both the relative autonomy and interdependence of human beings [70] — facilitating mutual respect and self-responsibility at the same time-and thus, sets the stage for co-creative learning and working. As a principles-based approach, it can theoretically be used with all kinds of group settings, regardless of the underlying worldview, and seems to be a promising approach for gently paving the way toward integrative education of HEIs 4.0. HEI leaders could therefore offer personnel development courses to lecturers of all levels on the TCI approach to facilitate a systemic upgrade of teaching methods. Furthermore, HEIs could initiate courses or information material on other didactical topics such as competency-based learning, blended learning, whole person education, research-based learning, and education for sustainable development (see e.g., [71,72]).

Research. The transdisciplinary living lab approach illustrates how a University or HEI 4.0 can attempt to contribute to sustainable development through novel research practices. The basic idea is to "leverage the campus as a test bed for sustainability" [73], integrating faculty, staff, researchers, and students into the process and using rapid prototyping methodologies for finding local solutions for global sustainability challenges. Living labs are moreover described as "open innovation ecosystems based on a systematic user co-creation approach" and have similarities to approaches such as real world laboratories, urban transition labs, and transformation labs [57] (cf. 32). In essence, they are focused on real-world application and effective problem solving through collaborative and open research. As such, living labs are not confined to the research category, but strongly interlink research with education, campus operations, and outreach, mirroring the cross-sector collaboration that is needed for promoting sustainable development. However, while the living lab approach is still emerging and preparing the ground for the integrative HEI 4.0, HEIs should not forget to also strengthen sound research practices on all levels, for example, by supporting open access publication or by prescribing study pre-registration to fight $p$-hacking [74,75].

Governance. As the example of living labs goes to show, governance for sustainable development will increasingly be framed as a community task with the advent of postmodern HEIs 3.0 and integrative HEIs 4.0. According to Niedlich et al. [9] (p. 11), HEIs will then describe their purpose as that of being a change agent and not merely a knowledge producer, closely tied to civil society and other external actors. In this way, HEI management becomes a part of the community. Furthermore, sustainability governance will increasingly be based on a whole-institution approach and facilitate cross-sectional and inter-organizational decision-making processes. This includes pursuing multiple dimensions of 
sustainability and other cross-cutting issues simultaneously in an ambidextrous approach [9] (cf. p. 14). Living labs are one possible expression of integrative sustainability governance at HEIs 4.0, especially at older institutions. However, smaller and more rural institutions might be better able to make the transition toward postmodern and integrative practices of sustainability governance than larger institutions with a long history of traditional and modern practices.

In essence, the development of higher education can be described as a process of progressively opening up to stakeholders of all kinds and of integrating participatory methods. This movement of opening up enables HEIs to keep up with societal change and to provide learning arrangements that not only address cognitive development, but also emotional and even moral and spiritual development.

Thus, the main strategy to deal with increasing complexity is argued to be found in the facilitation of systemic development toward more integrative approaches, while trying to consolidate lessons and standards from preceding phases. As HEIs are invariably stratified organizations including a multitude of subsystems and worldviews, this strategy should be consciously adopted as a stratified or multi-dimensional approach, enabling each subsystem of a given HEI to take the next necessary step or to strengthen what is working well. In other words, HEIs should be wary of a one-size-fits-all approach and address each subsystem independently, allowing for stratified, parallel development with a general tendency toward integrative practices, as reflected in the whole-institution approach for sustainability governance and the broader model of University or HEI 4.0.

As the complexity of this task could easily overwhelm local change agents, we have found that this main strategy is often supported by inter-organizational networking among peers. Moreover, inter-organizational collaboration can be seen as a central organizational element of the University 4.0 model. Therefore, inter-organizational networking will be discussed in the following section as the second, more specialized strategy for dealing with increased complexity.

\section{The Role of Inter-Organizational Networks for Higher Education Development}

To reiterate, if higher education institutions (HEIs) are willing to meet the complex challenge of sustainable development (SD), they would do well to raise their general capacity to deal with complexity. This strategy of living up to SD by upgrading the metaphorical operating system of a given HEI has been argued to be the primary strategy of choice for sustainable HEI development. However, if dealing with evermore complexity can be described as a process of opening up to various stakeholders and thus increasing inter-organizational collaboration, how can this process be designed and formally supported?

One of the more tangible ways of inter-organizational communication and collaboration is that of participating in specialized networks, especially for cross-cutting topics such as SD. The second strategy to deal with increasingly complex demands is therefore described in the following as the strategy of inter-organizational networking. As Kurt de Wit [76] and Jeffrey Selingo [77] point out, successful HEIs are increasingly networked and work in alliances to tackle common challenges. Their networking activities include both internal and external stakeholders. In this paper, we are going to focus on the latter.

Scientific conceptions of networks come in many shapes and sizes. One dominant line of research views basically all relationships as part of a bigger network of relationships that make up society as a whole [78]. This perspective is built on the idea that "networks do not have boundaries" [79] (p. 1039) and forms the basis for quantitative network analysis and the famous "small worlds" theorem.

However, another line of research uses the term network to describe informal patterns of coordination that are based on personal relations and that bypass formal ways of decision making [80]. Thus, from this point of view, networks are seen as a special form of social coordination and are usually linked to phenomena such as cliques, corruption, and insider relationships [78].

Both lines of research have in common that they highlight the power of personal relationships for the distribution of information and resources. In this paper, we are assuming a middle ground position: on the basis of the works of Heiko Kleve [81,82], we regard networks as both formal and informal patterns of coordination that cut across other forms of organizations in highly specialized 
societies, such as higher education institutions or enterprises, or even sectors such as politics and higher education in general. Networks thus fulfill the function of bridging units that are functioning separately from one another in order to solve problems that are hard to solve for each unit separately. In this sense, phenomena such as public-private partnerships can be seen as networks [83].

According to Kleve, networks are formed when highly differentiated expert organizations (e.g., hospitals, enterprises, or HEIs) are not able to solve current issues on their own or when the contribution of formal ways to problem solving is doubted [82] (cf. p. 354). In line with the sociological systems theory of Niklas Luhmann [84], networks are characterized by the principle of personal reciprocity, i.e., by the binary code of giving and taking [82] (p. 360). In other words, the power of networks relies on trust, the principle of mutual exchange, as well as on mutual expectations.

In higher education, inter-organizational networks are formed to enable flow of information and problem solving across organizations, usually with respect to specialized administrative and operative topics like that of digitalization, international recruitment, legal affairs, or online education [77]. Furthermore, cross-cutting research topics such as sustainable development or advancement of research methods can also be the focal point of inter-organizational networks, connecting professionals experiencing similar challenges.

Building on Kleve's conception, the success of inter-organizational networks should be dependent on the degree of exchange (and thus, giving and taking) within the network and on the degree of perceived reduction of complexity among its members. Ideally, both factors would help members with solving issues-both complex and trivial-at their respective organizations. However, we propose that the prototypical conception of a network differs greatly depending on the worldviews of the participating members, be they individuals or organizations. Hence, if network managers want to initiate lively exchange and to reduce the perceived complexity of their network's members, they should account for different expectations and worldviews.

In Section 4.1, we will thus bring forward different conceptions of networks on the basis of Graves' worldview model (see Section 2.2) and discuss implications for network management, especially in the context of higher education and sustainable development. The theoretical exploration is followed by a short case study in Section 4.2 on how the presented ideas were applied in the network "HOCH-N". The project name HOCH-N stands for "Sustainability at Higher Education Institutions". The project was funded by the Federal Ministry of Education and Research (BMBF), Germany to conduct research on sustainability at HEIs from the view of a whole-institutional approach and to build a network of HEI members that engage in SD $[4,85]$. This project serves as an empirical back-drop for the presented ideas. The authors are part of the HOCH-N network management team and thus have had the opportunity to compare theoretical ideas on networks with practical experiences.

\subsection{Network Management from a Worldview Perspective}

When HEIs are increasingly seeking out inter-organizational networks in order to tackle complex cross-cutting issues, the question has to be answered how these networks should be managed. As pointed out above, the term network is used to describe social phenomena of very different scope and sizes-a circumstance that complicates the conscious initiation and coordination of networks. If all relationships are part of a large invisible network, how could networks possibly be managed? Or if networks are seen as informal corrupt cliques, is their use not immoral per se?

However, combining the idea of networks as inter-organizational patterns of giving and taking with the idea of systemic worldviews, the following table and paragraphs are intended to highlight different conceptions of networks and principles of network management. From a worldview perspective, four types of networks are relevant for the advancement of HEIs or other expert organizations (see Table 3). These four types could be preceded by a fifth type of network, but as this one would indeed be marked by the aforementioned bypassing of formal decision making (and therefore, disposed to corruption), it is not included as a viable or advisable basis for deliberate network management. 
Table 3. Four types of networks from a worldview perspective.

\begin{tabular}{|c|c|c|c|c|}
\hline & Network Type 1.0 & Network Type 2.0 & Network Type 3.0 & Network Type 4.0 \\
\hline label & traditionalist & modern & postmodern & integrative \\
\hline $\begin{array}{c}\text { motivation to participate in } \\
\text { a network }\end{array}$ & $\begin{array}{l}\text { staying in synch with the herd; } \\
\text { standing and fighting together }\end{array}$ & $\begin{array}{l}\text { staying in touch with the best; finding } \\
\text { an audience; bartering of ideas with } \\
\text { peers; reaching influential people }\end{array}$ & $\begin{array}{l}\text { meeting like-minded people; finding } \\
\text { support and supporting others; } \\
\text { sharing challenges with peers }\end{array}$ & $\begin{array}{l}\text { sparking and finding inspiration; } \\
\text { co-creating solutions for common } \\
\text { challenges }\end{array}$ \\
\hline conception of giving & $\begin{array}{l}\text { administering; providing; } \\
\text { offering; depositing }\end{array}$ & investing (ROI) & tending needs; paying it forward & $\begin{array}{c}\text { sharing gifts; helping to build } \\
\text { a thriving system }\end{array}$ \\
\hline taking is seen as & $\begin{array}{l}\text { justified (based on principles and } \\
\text { liability) }\end{array}$ & a reward and the point of the exchange & $\begin{array}{l}\text { selfish or as a cause for feeling } \\
\text { indebted }\end{array}$ & $\begin{array}{l}\text { an opportunity for growth; a means } \\
\text { for building something bigger }\end{array}$ \\
\hline character & brotherhood/lobby & competitive game/market & campfire & jazz session \\
\hline $\begin{array}{l}\text { types and characteristics of } \\
\text { meetings and events }\end{array}$ & $\begin{array}{l}\text { official, regular, structured, } \\
\text { and orchestrated }\end{array}$ & $\begin{array}{l}\text { big, output oriented, scientific } \\
\text { conference with shorter sessions and } \\
\text { market of ideas }\end{array}$ & $\begin{array}{l}\text { conference or camp with workshops; } \\
\text { organic and plant-based food; cosy }\end{array}$ & $\begin{array}{l}\text { hubs, labs, and camps; leaving space } \\
\text { for experimentation }\end{array}$ \\
\hline $\begin{array}{l}\text { implications for network } \\
\text { management }\end{array}$ & $\begin{array}{l}\text { focus on stipulating standards; } \\
\text { political work; adopting resolutions; } \\
\text { strict admission criteria; clear network } \\
\text { structure with committees, boards etc.; } \\
\text { communication with authorities in the } \\
\text { field }\end{array}$ & $\begin{array}{l}\text { focus on high quality input and } \\
\text { visibility; highlighting best practices; } \\
\text { organizing conferences; enabling } \\
\text { exchange and opportunities for } \\
\text { presentations; }\end{array}$ & $\begin{array}{l}\text { focus on creating a safe space to } \\
\text { discuss common problems; } \\
\text { strengthening bonds; organizing } \\
\text { workshops; sustainable catering; } \\
\text { providing resources }\end{array}$ & $\begin{array}{l}\text { focus on enabling co-creation and } \\
\text { innovation; holding the space; } \\
\text { highlighting creativity methods and } \\
\text { inspiring solutions; open source and } \\
\text { sharing culture }\end{array}$ \\
\hline examples from $\mathrm{HOCH}-\mathrm{N}$ & $\begin{array}{l}\text { three distinct levels of membership } \\
\text { (from individuals to institutions, } \\
\text { criteria based); } \\
\text { practitioner's guides; support by } \\
\text { federal ministry; consulting committee } \\
\text { with experts }\end{array}$ & $\begin{array}{l}\text { practitioner's guides with toolboxes } \\
\text { and best practices; collection of more } \\
\text { than } 700 \text { best practices on digital map; } \\
\text { scientific and networking conferences }\end{array}$ & $\begin{array}{l}\text { stakeholder-oriented interdisciplinary } \\
\text { research; practitioner's guides; } \\
\text { regional networking hubs; digital map } \\
\text { of sustainability researchers in } \\
\text { Germany; free resources }\end{array}$ & $\begin{array}{l}\text { co-creation hubs with innovative } \\
\text { methods (LEGO Serious Play®, } \\
\text { systemic constellations, Theory U) } \\
\text { focused on systemic transformation } \\
\text { and whole-institutional approach }\end{array}$ \\
\hline
\end{tabular}


Network type 1.0. When a network is characterized by more traditional traits (see Section 2.2), it will likely be focused around the idea of finding and voicing common standards and concerns. Likewise, traditionalist network members might participate in a network in order to stay in synch with their peers and to comply with authorities in the field. If a network manager considers her network to be a more traditional network type 1.0, she could thus focus on more formal rules for admission and meetings, on providing orientation for its members, and on enabling communication with experts and authorities in the field.

Network type 2.0. A network type 2.0, based on the modern worldview, would in contrast be geared toward friendly competition among its members, seeking to learn from the best, and to find an audience themselves. Giving and taking are then seen more as a transaction and networking itself as an opportunity for marketing oneself or ideas. In order to fulfill the expectations of a network that is best characterized in terms of the modern worldview, network managers should then focus on providing plenty of opportunities for the presentation of ideas and personal exchange. Furthermore, it could be well-advised to champion best practices and to favor shorter and frequent sessions during events. With respect to higher education development, typical themes might include resource efficiency, quantitative methods, mainstream quantitative science, and digitalization.

Network type 3.0. When networks are formed around topics of social or environmental issues, they tend to focus much more on community building and workshops than on career advancement or efficient presentation of research results. A network type 3.0 is in essence built around the idea of mutual support and sharing, and giving and taking are likewise seen as a matter of tending needs and humble receiving. Its members might, therefore, expect more workshop-like formats during events, freely available resources, and low admission criteria. The topics of sustainable development or advancement of qualitative and transdisciplinary research lend themselves quite naturally to these postmodern network types 3.0. Network managers of more postmodern networks would therefore be well-advised to focus on dialogue, transparency, and responsible event hosting (especially with regards to catering).

Network type 4.0. When networks are more centered around the integrative worldview, they tend to be less predictable in their choice of tools and structures as their main focus lies on flexible problem solving and co-creative work with open outcomes. The main driver of a network type 4.0 seems to be the challenge of complexity and the desire to go beyond dogmatic and pre-defined solutions. While integrative networks might commit to a certain type of method (such as systemic constellations, LEGO Serious Play $囚$, or methods from Theory $U$ or the Art of Hosting), their key feature is that of co-creative work in the present moment-which can be likened to a jazz session, building both on a strong base of competence and on common standards while striving on present-moment interaction and improvisation.

In that regard, tools might be important for a network type 4.0, but only on the basis of mindful application and benevolent intentions as giving and taking are seen as a matter of sharing gifts. To set the stage for mindfulness, integrative networks often include relaxation techniques, meditation, or other practices from spiritual traditions. A network manager of an integrative network type 4.0 thus needs to fill the role of a facilitator, setting and holding the space for safe sharing of ideas. Because this type of interaction is rather atypical in mainstream scientific communities, integrative network events are usually either smaller-scale events (often labeled with alternative terms such as hubs, labs, or camps) or sub-tracks at larger, more typical scientific events.

Taking everything together, several distinct types of networks can be described through the lens of Clare W. Graves' worldview model. On the basis of the principles of systemic development laid out in Section 2.2.1, it is, however, unlikely that a network or its members will be a pure representation of one of the four network types. Nonetheless, network managers should be aware of the values and worldviews that are most prevalent in their respective field in order to promote coherent structures, facilitating the problem solving capabilities of networks. When the character of a network is experienced as incoherent to its contents, it puts the integrity and ultimately the liveliness and effectivity of the network at risk. 
All in all, we propose that the design of a network should be intended to roughly match the worldview of a network's members and, in short, meet the network's participants where they are. This will most likely lead to a multi-level approach, serving multiple worldviews at once, while stressing one or two in particular. A bias toward inclusion of integrative approaches (network type 4.0) might furthermore be called for when a network is dealing with a particularly challenging issue in order to facilitate effective and co-creative problem solving.

\subsection{Case Study: Managing the HOCH-N Network}

Some examples from the HOCH-N network on sustainability in higher education in Germany are to illustrate the application of the presented ideas and to find the first answers to research question B2: How can inter-organizational networks contribute to the integration of SD into HEIs and to the general systemic development of HEIs? The case study is intended to explore practical application of the aforementioned conceptions (Section 4.1), thereby inspiring self-reflection in the reader (cf. [13,14], see Section 1). Hence, it demonstrates how key structures, products, and services of the HOCH-N network are set up to serve different worldviews and to promote systemic transformation.

Being part of the HOCH-N network management team, we could build our analysis on both publicly available resources and on internal documents and discussions. As the first step, we identified the most pivotal aspects of the network's design and outputs. Thereafter, we analyzed both the conceptualization and realization of those aspects on the basis of Graves' model (see Sections 2.2.1 and 3.1) and its application to networks (see Section 4.1), identifying (a) main drivers of participation in the HOCH-N network and (b) the respective worldviews that are predominantly served.

\section{Case Study Results}

The general design of the HOCH-N network is mostly based around postmodern ideas (network type 3.0) as the HOCH-N network is intended to promote the inclusion of sustainable development into HEIs' practices and curricula and the topic itself is typically associated with a postmodern worldview. This includes free membership and resources, low admission criteria, stakeholder inclusion, and a focus on smaller regional events (in order to facilitate personal exchange and to minimize travel costs and carbon footprint). However, in order to make the network more resilient and agile, the core structures, tools, and products of $\mathrm{HOCH}-\mathrm{N}$ are designed to serve multiple worldviews at once, building on our own ideas and on empirical research on networks of HOCH-N network members [86,87].

To begin with, as HOCH-N is touching issues of both higher education politics and HEI governance, it has come to adopt certain traits of a more traditional network type 1.0. For example, three distinct levels of membership were defined with different barriers of entry. On the lowest level, each interested individual can participate. On the second level, members of HEIs can join HOCH-N individually, as long as they have attended a HOCH-N event. Moreover, level two members appear on the digital map (see below) and have to provide three best-practice examples concerning SD from their respective HEI as well as a short motivational statement for their membership. On the third level, HEIs as a whole can join $\mathrm{HOCH}-\mathrm{N}$ as long as they demonstrate their engagement for SD with examples in six different fields of action, have the explicit support of leadership, and fulfill further structural criteria (for example, publication of a sustainability report). This three-level membership structure is intended to serve both the need for hierarchy and structure (traditional network type 1.0) as well as the disposition toward community and inclusion (postmodern network type 3.0).

The most engaging feature of the HOCH-N network is probably to be found in the networking events for sustainability at HEIs, enabling personal networking, exchange of concepts and ideas, and collaborative work on common issues. As the project evolved, several types of events have proven to be vital. As we identified community building (network type 3.0) and innovative problem solving (network type 4.0) to be the main drivers for HOCH-N members to participate, the typical HOCH-N events have turned more and more into so called hubs with either a focus on regional networking or 
innovative methods. The latter are usually smaller-scale events or sub-tracks with a focus on systemic methods (like LEGO Serious Play®, systemic constellations [88], or methods from Theory U [41]) in order to build the needed capacity to deal with complexity (see Sections 2 and 3). This does not mean that more standard event formats and presentations of scientific results are not valued-these formats merely play a lesser role as the topic of SD is less linked to mainstream scientific careers.

Going beyond physical events, one of the key features of HOCH-N's website is the digital map of sustainable development at German HEIs (see Figure 2), programmed and maintained at the University of Hamburg [89,90]. As all level two members have to contribute a personal picture, a motivational statement, and have to highlight three examples of engagement for SD at their HEI, the map is able to fulfill several functions at once. First of all, it is intended to facilitate bilateral exchange via personal profiles as a kind of who-is-who of sustainability champions at German HEI (fitting network types 2.0 and 3.0). Moreover, it is also a rich collection of best-practices, with currently more than 700 entries from 250 individuals from 133 different German HEIs (again fitting network types 2.0 and 3.0), representing roughly a third of all German HEIs. The map is currently being re-programmed to include a novel search and database feature, enabling users to display, for example, all best-practices dealing with education for SD or SD governance (see [90] for the URL).

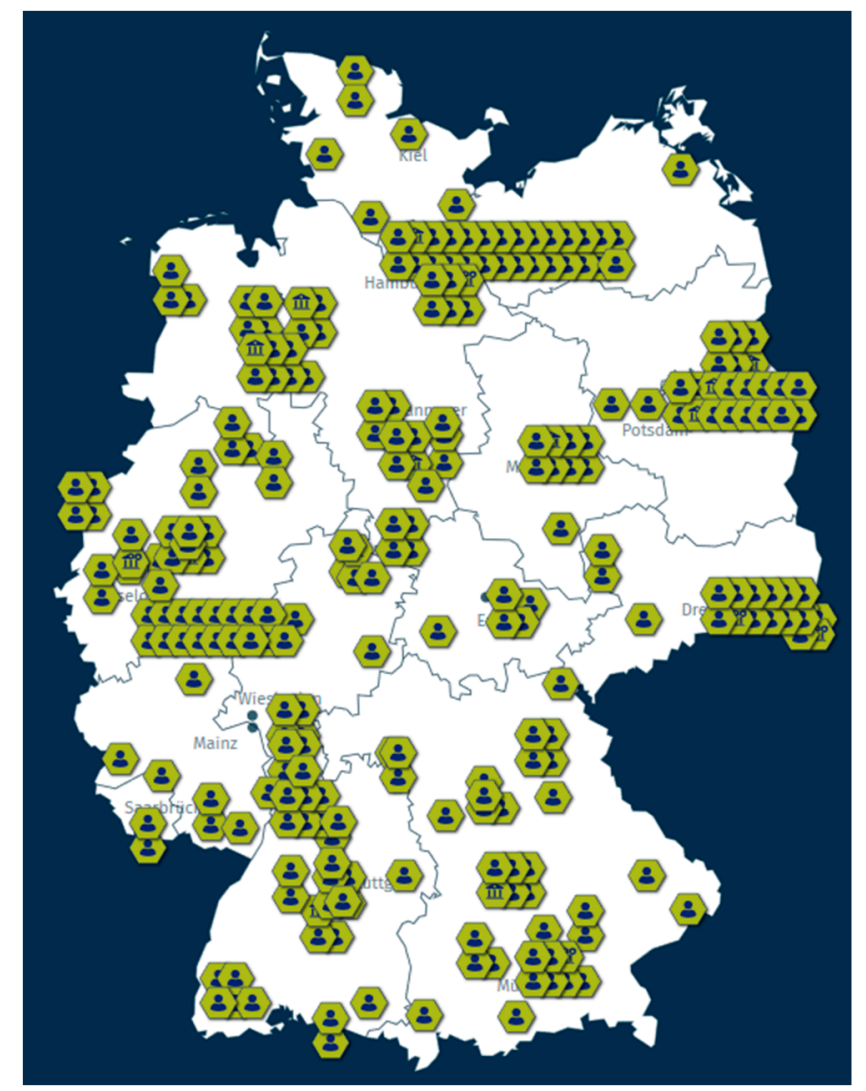

Figure 2. The HOCH-N digital map of sustainable development at German higher education institutions. Combs represent network members and link to individual profiles [90].

As HOCH-N was not only set up as a network but also as a research alliance, the project has also produced substantial results in six different fields of action: reporting [91], governance [7,9,92,93], teaching \& education [94,95], research [62,96], operations [97,98], and transfer [99,100]. The six corresponding work packages have published practitioner's guides (see references above), available free of charge as print versions and PDFs (currently, only the guide on sustainability governance is available in English). These guides represent a major milestone in advancing SD at German HEIs as they help to provide interested but inexperienced members of HEIs with overviews, checklists, guidelines, 
and inspiration for SD at HEIs. The practitioner's guides lend themselves to all four network types and thus help to ensure the success of the network. All guides will also be turned into short online video courses and merged on a common homepage to reflect the whole-institution approach, in line with the integrative worldview.

All in all, the HOCH-N network is intended to facilitate lively giving and taking, for example, by providing free resources and practitioner's guides, networking events, and by involving members and other stakeholders in the development of said resources. Its main focus is on serving the postmodern and integrative worldviews with networking events, innovation hubs, the digital map, and with practitioner's guides, while at the same time also serving and respecting both the traditional and modern worldview. Most key features were therefore designed to reflect a wide variety of needs. In this way, the HOCH-N networks tries to strengthen local change agents at HEIs and to provide them with inspiration through best practices, handbooks, and innovative methods, gently nudging systemic transformation toward a whole-institutional approach of SD.

\section{Discussion}

As members of the HOCH-N project, our work is focused on supporting HEIs in integrating sustainability into their education, research, governance, operations, reporting, and transfer, implementing the whole-institution approach. However, HEIs around the world are also facing the difficult task of dealing with multiple complex trends simultaneously while trying to maintain the ability to take action in times of uncertainty. Consequently, the implementation of measures for issues such as sustainable development often falls short. Otto Scharmer summarizes the challenge of implementing sustainable development in HEIs and society in general:

"The difficulties we have in meeting today's global challenges, such as implementing the 17 Sustainable Development Goals (SDGs) worldwide, are not caused by a knowledge gap. We have all the knowledge we need. The problem is a knowing-doing gap: a disconnect between our collective consciousness and our collective actions. ( ... ) To address these issues at their root requires two things: new platforms for cross-sector co-creation and an upgrade in the operating system that people use to collaborate-practices that facilitate a shift from ego-system to eco-system awareness." [6]

Similarly, we have proposed two main strategies for HEIs for dealing with the challenge of complexity: (a) promoting systemic development of a HEI by updating its self-concept and worldview, enabling the HEI to deal with more complexity, and (b) participating in inter-organizational networks in order to promote transformative capabilities and problem solving across organizations. Both strategies combined are argued to enable HEIs to deal with increasing levels of complexity in general and the challenge of sustainable development in particular.

In essence, the systemic development of higher education is laid out as one of progressively opening up to internal and external stakeholders and thus, embracing interconnected and open environments. Ideally, this enables HEIs to keep up with societal change and to deal with increasing complexity, gradually leaving professional silos behind and allowing co-creative problem solving and collaboration to occur.

As HEIs are stratified organizations consisting of diverse subsystems, this strategy should be consciously adopted as a multi-level approach, enabling each subsystem of a given HEI to take the next necessary step —or alternatively, to strengthen best practices at the current level of development. Consciously developing a stratified university or HEI following the integrative University 4.0 model requires the ability of change agents and leaders to tolerate ambiguity and tension, appreciating the value of each distinct worldview of each subsystem while still trying to plant the seed of systemic growth. It is thus dependent on the personal development of leaders and their ability to embrace uncertainty, as qualitative research by Barret C. Brown suggests [47]. Brown further concludes that in order for global sustainability to be achieved, leaders would need to build their decisions (a) on a "deep inner foundation"; (b) on the conscious application of systems theory, complexity theory, 
or integral theory; and (c) on mindfully responding to emerging topics by following an "adaptive design management" approach [47] (cf. 566).

As HEIs have to manage several complex issues at once, it might be argued that the simultaneity of trends would hinder general systemic development. However, some of these trends could actually accelerate systemic development by challenging predominant worldviews and processes. Specifically the trend of digitalization might indeed create windows of opportunity for systemic upgrades, as Giesenbauer [101] argues. For example, digital administration tools might facilitate the development from HEI 1.0 to 2.0 by promoting transparent process management; interactive tools might moreover facilitate the development from HEI 2.0 to 3.0 by increasing participation, stakeholder engagement, and transparency; and new tools for networking and collaboration might finally facilitate the development from HEI 3.0 to 4.0 by enabling inter-organizational and co-creative work processes.

The latter aspect hints at a particular feature of integrative HEIs 4.0 as those are expected to be highly networked. Organizational psychologist Peter Kruse [102] proposes that the challenge of rising complexity can only be successfully managed when the density of network connections in a given organization are increased significantly in order to tap into the organization's inherent problem solving capacities and intelligence. Analogous to neural networks, inter- and intra-organizational networks thrive on resonance and exchange of information in order to create viable solutions. Once different members are connected and resonate with each other, co-creative solutions can potentially emerge. Thus, a higher network density increases the chance of effective problem solving.

In this sense, inter-organizational networks play an important role in enabling HEIs to promote systemic development. At the very least, network managers should reflect the worldviews and expectations of their networks' members in the design of their network in order to assist fruitful exchange. Ideally, they would additionally reflect how the systemic development of their members' organizations is likely going to unfold and design their network in a way that facilitates and even accelerates further systemic upgrades. The case study of the HOCH-N network illustrates that different structural features, events, and products can be used to serve different worldviews in order to build an agile network.

The case study is not without limitations. First and foremost, the authors are part of the network management team themselves and thus, are possibly biased. Furthermore, a single case delivers mainly anecdotal evidence. At the same time, the case study goes to show that accounting for different worldviews can help to inform the conception of a network, strengthening its strategic flexibility. Theoretically, this should improve a network's impact and help its members with the task of systemic transformation. However, while we are confident that $\mathrm{HOCH}-\mathrm{N}$ supports the systemic transformation of HEIs in Germany toward a whole-institution approach and a University 4.0 model, these effects are difficult to operationalize and quantify. Further research, both qualitative and quantitative, would be needed to substantiate our findings and convictions.

Moreover, even while cross-sector collaboration might be needed for effective societal solutions, its implementation can be challenging, especially with regards to different narratives and organizing principles across sectors [103]. Thus, the diversity of inter-organizational networks does not only represent an asset for co-creativity, but also a liability for effective coordination. Network managers should therefore keep an eye on communication practices and trust levels within their network as co-creative collaboration is dependent on both.

\section{Conclusions}

How can higher education institutions become change agents for sustainable development while also having to respond to increasingly complex demands simultaneously? These demands include massification, globalization, marketization, and digitalization. The pressure is further intensified by increased competition for grants and placements in rankings. In order to deal with the increased complexity, two main strategies can be identified: (a) promoting general systemic development of a given HEI (upgrading the HEI's "operating system"), progressively opening up to various 
stakeholders and focusing on co-creative collaboration, and (b) participating in inter-organizational networks in order to find inspiration for dealing with challenging trends. The multi-dimensional and networked organizational model of an integrative University 4.0 is argued to be suitable for following both strategies and consequently managing complexity.

Building on Clare. W. Graves model of systemic development, both general systemic development as well as the development of HEIs and inter-organizational networks can be described with a single coherent framework, supplying change agents with a navigational tool for systemic development. Further research is needed to elaborate on the presented ideas and to test their practical application.

All in all, our research suggests that it would be advisable for HEI management to build on the idea of a University 4.0, focusing on increased collaboration, co-creativity, and general systemic development. If higher education institutions are to contribute to mastery of pressing societal issues such as climate change and global migration, they should therefore reflect their dominant worldviews, making sure that they are not unnecessarily stuck in practices that were developed during very different times-e.g., to disseminate absolute truths in pre-democratic societies (HEI 1.0) or to standardize the scientific process in the Modern Age (HEI 2.0). While these phases were necessary for the development of higher education and their best practices still hold value, HEIs should progressively increase collaboration with stakeholders of all kinds in the generation of both knowledge and solutions, requiring increased intra- and inter-organizational network density.

In this way, adopting the concept of an integrative HEI or University 4.0 could enable HEIs to deal with the complex demands of the 21st century. Moreover, network managers could support the systemic transformation of HEIs by designing integrative inter-organizational networks that are focused on reducing perceived complexity and inspiring lively exchange. Both strategies combined might help HEIs to live up to the challenge of sustainable development and to become change agents for a sustainable future.

Author Contributions: Conceptualization, B.G. and G.M.-C.; writing-original draft preparation, review and editing, B.G.; supervision, G.M.-C. All authors have read and agreed to the published version of the manuscript.

Funding: This research was funded by the German Federal Ministry of Education and Research (BMBF), grant number 13NKE007A.

Acknowledgments: We would like to thank our reviewers for their considerate and helpful comments.

Conflicts of Interest: The authors declare no conflict of interest.

\section{References}

1. Barth, M.; Rieckmann, M. State of the Art in Research on Higher Education for Sustainable Development. In Routledge Handbook of Higher Education for Sustainable Development; Barth, M., Michelsen, G., Rieckmann, M., Thomas, I., Eds.; Routledge; Earthscan from Routledge: London, UK, 2016; pp. 100-113.

2. Altbach, P.G. The complex roles of universities in the period of globalization. In Higher Education in the World 3-Higher Education: New Challenges and Emerging Roles For Human and Social Development; Global University Network for Innovation, Ed.; Palgrave Macmillan: London, UK, 2008; pp. 5-14.

3. Giesenbauer, B.; Tegeler, M. The Transformation of Higher Education Institutions Towards Sustainability from a Systemic Perspective. In Universities as Living Labs for Sustainable Development; Leal Filho, W., Salvia, A.L., Pretorius, R.W., Brandli, L.L., Manolas, E., Alves, F., Azeiteiro, U., Rogers, J., Shiel, C., Do Paco, A., Eds.; Springer International Publishing: Cham, Germany, 2020; pp. 637-650. ISBN 978-3-030-15603-9.

4. Bassen, A.; Schmitt, C.T.; Stecker, C. Nachhaltigkeit an Hochschulen: Entwickeln-vernetzen-berichten (HOCH-N). uwf UmweltWirtschaftsForum 2017, 25, 139-146. [CrossRef]

5. Scharmer, C.O. Vertical Literacy: Reimagining the 21st-Century University. Available online: https://medium.com/presencing-institute-blog/vertical-literacy-12-principles-for-reinventing-the-21stcentury-university-39c2948192ee (accessed on 2 May 2019).

6. Scharmer, C.O. Education is the kindling of a flame: How to reinvent the 21st-century university. Available online: https://www.huffingtonpost.com/entry/education-is-the-kindling-of-a-flame-how-to-reinvent_us_ 5a4ffec5e4b0ee59d41c0a9f (accessed on 25 March 2019). 
7. Bauer, M.; Bormann, I.; Kummer, B.; Niedlich, S.; Rieckmann, M. Sustainability Governance at Universities: Using a Governance Equalizer as a Research Heuristic. High. Educ. Policy 2018, 31, 491-511. [CrossRef]

8. Mader, C.; Scott, G.; Abdul Razak, D. Effective change management, governance and policy for sustainability transformation in higher education. Sustainability 2013, 4, 264-284. [CrossRef]

9. Niedlich, S.; Kummer, B.; Bauer, M.; Rieckmann, M.; Bormann, I. Cultures of sustainability governance in higher education institutions: A multi-case study of dimensions and implications. Higher Educ. Q 2019, 1-18. [CrossRef]

10. Beck, D.; Cowan, C.C. Spiral dynamics. In Mastering Values, Leadership and Change: Exploring the new Science of Memetics; Blackwell: Malden, MA, USA, 2006; ISBN 9781405133562.

11. Graves, C.W. Human nature prepares for a momentous leap. Futurist 1974, 8, 72-87.

12. Graves, C.W. Levels of Human Existence. Transcription of a Seminar at the Washington School of Psychiatry, October 16, 1971; Lee William, R., Ed.; ECLET Publishing: Santa Barbara, CA, USA, 2002; ISBN 097247420X.

13. Wals, A.E.J.; Walker, K.E.; Corcoran, P.B. The Practice of Sustainability in Higher Education: A Synthesis. In Higher Education and the Challenge of Sustainability: Problematics Promise, and Practice; Corcoran, P.B., Ed.; Kluwer, Acad. Publ: Dordrecht, The Netherlands, 2009; pp. 347-348. ISBN 1-4020-2026-0.

14. Wals, A.E.J.; Alblas, A.H. School-based Research and Development of Environmental Education: A case study. Environ. Educ. Research 1997, 3, 253-267. [CrossRef]

15. The World-Class University and Ranking: Aiming Beyond Status; Sadlak, J.; Liu, N.C. (Eds.) UNESCO-CEPES: Bucharest, Romania, 2007.

16. Giesenbauer, B.; Müller-Christ, G. Mit den Sustainable Development Goals zu einer sinnhaften und nachhaltigen Unternehmensführung?: Systemische Evolutionsstufen als Unterscheidungsmerkmal für unterschiedliche Zugänge von Unternehmen. In Im Brennpunkt: Zukunft des nachhaltigen Wirtschaftens in der Digitalen Welt; Rogall, H., Binswanger, H.C., Ekardt, F., Grothe, A., Hasenclever, W.-D., Hauchler, I., Jänicke, M., Kollmann, K., Michaelis, N.V., Nutzinger, H.G., et al., Eds.; Metropolis Verlag: Marburg, Germany, 2018; pp. 281-294. ISBN 978-3-7316-1339-8.

17. Müller-Christ, G.; Giesenbauer, B. Integrales Ressourcenmanagement: Leitplanken einer nachhaltigkeitsbezogenen Möglichkeitswissenschaft. In Möglichkeitswissenschaften: Ökonomie mit Möglichkeitssinn; Hochmann, L., Graupe, S., Korbun, T., Panther, S., Schneidewind, U., Eds.; Metropolis Verlag: Marburg, Germany, 2019; pp. 307-332.

18. Brys, Z.; Bokor, P. Evaluation of Ken Wilber's Integral Psychology From a Scientific Perspective. J. Spiritual. Mental Health 2013, 15, 19-33. [CrossRef]

19. World Commission on Environment and Development. Our Common Future. A/42/427. 1987. Available online: https://sustainabledevelopment.un.org/milestones/wced (accessed on 25 March 2019).

20. Implementing Sustainable Development at University Level. A Manual of Good Practice; Leal Filho, W., MacDermott, F., Padgham, J., Eds.; European Research and Training Centre on Environmental Education: Bradford, UK, 1996; ISBN 1851431497.

21. Lozano, R. Incorporation and institutionalization of SD into universities: Breaking through barriers to change. J. Clin. Prod. 2006, 14, 787-796. [CrossRef]

22. Leal Filho, W. Teaching sustainable development at university level: Current trends and future needs. J. Balt. Sci. Educ. 2010, 9, 273-284.

23. Rieckmann, M. Future-oriented higher education: Which key competencies should be fostered through university teaching and learning? Futures 2012, 44, 127-135. [CrossRef]

24. United Nations. Transforming our world: The 2030 agenda for sustainable development. A/RES/70/1. 2015. Available online: https://sustainabledevelopment.un.org/post2015/transformingourworld (accessed on 25 March 2019).

25. Hugé, J.; Block, T.; Waas, T.; Wright, T.; Dahdouh-Guebas, F. How to walk the talk? Developing actions for sustainability in academic research. J. Clean. Prod. 2016, 137, 83-92. [CrossRef]

26. Lozano, R.; Ceulemans, K.; Alonso-Almeida, M.; Huisingh, D.; Lozano, F.J.; Waas, T.; Lambrechts, W.; Kovačič Lukman, R.; Hugé, J. A review of commitment and implementation of sustainable development in higher education: Results from a worldwide survey. J. Clean. Prod. 2015, 108, 1-18. [CrossRef]

27. Peer, V.; Stoeglehner, G. Universities as change agents for sustainability-framing the role of knowledge transfer and generation in regional development processes. J. Clean. Prod. 2013, 44, 85-95. [CrossRef] 
28. Thomas, I. Sustainability in tertiary curricula: What is stopping it happening? Int. J. Sustain. Higher Educ. 2004, 5, 33-47. [CrossRef]

29. Blanco-Portela, N.; Benayas, J.; Pertierra, L.R.; Lozano, R. The Integration of Sustainability in Higher Education Institutions: A Review of Drivers of and Barriers to Organisational Change and Their Comparison Against Those Found of Companies. J. Clean. Prod. 2017, 166, 563-578. [CrossRef]

30. Müller-Christ, G.; Giesenbauer, B.; Tegeler, M.K. Die Umsetzung der SDGs im deutschen Bildungssystem -Studie im Auftrag des Rats für Nachhaltige Entwicklung der Bundesregierung. Zeitschrift Int. Bildungsforschung Entwicklungspädagogik 2018, 41, 19-26.

31. Leal Filho, W. Dealing with misconceptions on the concept of sustainability. Int. J. Sustain. Higher Educ. 2000, 1, 9-19. [CrossRef]

32. Moore, J.; Pagani, F.; Quayle, M.; Robinson, J.; Sawada, B.; Spiegelman, G.; van Wynsberghe, R. Recreating the university from within. Int. J. Sustain. Higher Educ. 2005, 6, 65-80. [CrossRef]

33. Lattu, A.; Cai, Y. Tensions in the Sustainability of Higher Education-The Case of Finnish Universities. Sustainability 2020, 12, 1941. [CrossRef]

34. Hedlund-de Witt, A. Worldviews and the Transformation to Sustainable Societies. An Exploration of the Cultural and Psychological Dimensions of our Global Environmental Challenges. Ph.D. Thesis, VU University Amsterdam, Amsterdam, The Netherlands, 2013.

35. Hedlund-de Witt, A. Rethinking Sustainable Development: Considering How Different Worldviews Envision "Development" and "Quality of Life". Sustainability 2014, 6, 8310-8328. [CrossRef]

36. Hedlund-de Witt, A. The Integrative Worldview and its Potential for Sustainable Societies. Worldviews 2014, 18, 191-229. [CrossRef]

37. Van Marrewijk, M. The Cubrix, an Integral Framework for Managing Performance Improvement and Organisational Development. Technol. Invest. 2010, 1, 1-13. [CrossRef]

38. Van Marrewijk, M.; Werre, M. Multiple levels of corporate sustainability. J. Business Ethics 2003, 44, 107-119. [CrossRef]

39. Müller-Christ, G. Nachhaltigkeitsforschung in einer transzendenten Entwicklung des Hochschulsystems—Ein Ordnungsangebot für Innovativität. In Innovation in der Nachhaltigkeitsforschung: Ein Beitrag zur Umsetzung der UNO Nachhaltigkeitsziele; Leal Filho, W., Ed.; Springer: Berlin/Heidelberg, Germany, 2017; pp. 161-180. ISBN 978-3-662-54358-0.

40. Wilber, K. A Theory of Everything. An Integral Vision for Business, Politics, Science and Spirituality; Shambhala: Boston, MA, USA, 2001; ISBN 9781570628559.

41. Scharmer, C.O. The Essentials of Theory, U. Core Principles and Applications; Berrett-Koehler: Oakland, CA, USA, 2018; ISBN 978-1523094400.

42. Fallis, G. Multiversities, Ideas, and Democracy, 2nd ed.; University of Toronto Press: Toronto, ON, Canada, 2007; ISBN 9780802092403.

43. Laloux, F. Reinventing Organizations. A Guide to Creating Organizations Inspired by the Next Stage of Human Consciousness, 5th ed.; Nelson Parker: Brussels, Belgium, 2014; ISBN 2960133501.

44. Van Egmond, N.D.; de Vries, H.J.M. Sustainability: The search for the integral worldview. Futures 2011, 43, 853-867. [CrossRef]

45. Hahn, T.; Pinkse, J.; Preuss, L.; Figge, F. Tensions in Corporate Sustainability: Towards an Integrative Framework. J. Bus. Ethics 2015, 127, 297-316. [CrossRef]

46. Hahn, T.; Figge, F.; Pinkse, J.; Preuss, L. A Paradox Perspective on Corporate Sustainability: Descriptive, Instrumental, and Normative Aspects. J. Bus. Ethics 2018, 148, 235-248. [CrossRef]

47. Brown, B.C. Leading complex change with post-conventional consciousness. J. Organ. Change Manag. 2012, 25, 560-577. [CrossRef]

48. Scharmer, C.O.; Theory, U. Leading from the future as it emerges: The social technology of presencing, 2nd ed.; Berrett-Koehler: San Francisco, CA, USA, 2016; ISBN 9781626567986.

49. Shapiro, A.; Permuth, S. Stratification, in Organizations. In Encyclopedia of Educational Leadership and Administration; English, F.W., Ed.; SAGE: Thousand Oaks, CA, USA, 2011; ISBN 9780761930877.

50. Altbach, P.G.; Reisberg, L.; Rumbley, L. Trends in Global Higher Education. Tracking an Academic Revolution; Sense Publishers; UNESCO Publishing: Rotterdam, The Netherlands, 2010; ISBN 9460913393.

51. Graves, C.W. Levels of Existence Related to Learning Systems. In Proceedings of the Ninth Annual Conference of the National Society for Programmed Instruction, Rochester, NY, USA, 31 March 1971. 
52. Kerr, C. The Uses of the University. With a New Chapter and Preface, 5th ed.; Harvard University Press: Cambridge, MA, USA, 2001; ISBN 0674005325.

53. Private Higher Education. A Global Revolution; Altbach, P.G., Levy, D.C., Eds.; Sense Publishers: Rotterdam, The Netherlands, 2005; ISBN 9789077874080.

54. Lewin, K. Feldtheorie; Klett-Cotta: Bern, Germany, 1982; ISBN 3-12-935140-X.

55. Laptev, A.V.; Efimov, V.S. New Generation of Universities. University 4.0. Journal of Siberian Federal University. Hum. Soc. Sci. 2016, 11, 2681-2696. [CrossRef]

56. Efimov, V.; Lapteva, A. University 4.0: Philosophical Analysis. In Proceedings of the 10th Annual International Conference of Education, Research and Innovation, Seville, Spain, 16-18 November 2017; Gómez Chova, L., López Martínez, A., Candel Torres, I., Eds.; IATED, 2017; pp. 589-596.

57. Verhoef, L.; Bossert, M. The University Campus as a Living Lab for Sustainability. A Practitionier's Guide and Handbook; Delft University of Technology: Delft, Germany; Hochschule für Technik Stuttgart: Stuttgart, Germany, 2019.

58. Schneidewind, U. Von der nachhaltigen zur transformativen Hochschule: Perspektiven einer "True University Sustainability". UmweltWirtschaftsForum 2014, 22, 221-225. [CrossRef]

59. Murray, P.; Goodhew, J.; Murray, S. The heart of ESD: Personally engaging learners with sustainability. Environ. Educ. Res. 2014, 20, 718-734. [CrossRef]

60. Scharmer, C.O.; Kaufer, K. Leading from the emerging future. From ego-system to eco-system economies, 1st ed.; Berrett-Koehler: San Francisco, CA, USA, 2013; ISBN 1605099260.

61. Schneidewind, U. Transformative Literacy. Gesellschaftliche Veränderungsprozesse verstehen und gestalten. GAIA Ecol. Perspect. Sci. Soc. 2013, 22, 82-86.

62. Vogt, M.; Weber, C. The Role of Universities in a Sustainable Society. Why Value-Free Research is Neither Possible nor Desirable. Sustainability 2020, 12, 2811. [CrossRef]

63. Stensaker, B.; Lee, J.J.; Rhoades, G.; Ghosh, S.; Castiello-Gutiérrez, S.; Vance, H.; Çalıkoğlu, A.; Kramer, V.; Liu, S.; Marei, M.S.; et al. Stratified University Strategies: The Shaping of Institutional Legitimacy in a Global Perspective. J. Higher Educ. 2019, 90, 539-562. [CrossRef]

64. Wissema, J. Towards the Third Generation University; Edward Elgar Publishing: Cheltenham, UK, 2009; ISBN 9781848446182.

65. Podger, D.M.; Mustakova-Possardt, E.; Reid, A. A whole-person approach to educating for sustainability. Int. J. Sustain. Higher Educ. 2010, 11, 339-352. [CrossRef]

66. Meyerhuber, S. Theme-Centered Interaction for Educating Future Leaders: Applied Social Psychology for Teaching Academics to Act Socially Sustainably in Organisations. In Theme Centered Interaction (TCI) in Higher Education: A Didactic Approach for Sustainable and Living Learning; Meyerhuber, S., Reiser, H., Scharer, M., Eds.; Springer: Cham, Germany, 2019; pp. 3-56. ISBN 978-3-030-01047-8.

67. Theme Centered Interaction (TCI) in Higher Education. A Didactic Approach for Sustainable and Living Learning; Meyerhuber, S.; Reiser, H.; Scharer, M. (Eds.) Springer: Cham, Germany, 2019; ISBN 978-3-030-01047-8.

68. Stollberg, D.; Schneider-Landolf, M. Living Learning. In Handbook of Theme-Centered Interaction (TCI); Schneider-Landolf, M., Spielmann, J., Zitterbarth, W., Eds.; Vandenhoeck \& Ruprecht: Göttingen, Germany, 2017; pp. 137-146. ISBN 9783525451908.

69. Hoffmann, S.G. The Disturbance Postulate. In Handbook of Theme-Centered Interaction (TCI); Schneider-Landolf, M., Spielmann, J., Zitterbarth, W., Eds.; Vandenhoeck \& Ruprecht: Göttingen, Germany, 2017; pp. 95-100. ISBN 9783525451908.

70. Faßhauer, U. The Existential-Anthropological Axiom. In Handbook of Theme-Centered Interaction (TCI); Schneider-Landolf, M., Spielmann, J., Zitterbarth, W., Eds.; Vandenhoeck \& Ruprecht: Göttingen, Germany, 2017; pp. 75-79. ISBN 9783525451908.

71. Barth, M.; Godemann, J.; Rieckmann, M.; Stoltenberg, U. Developing key competencies for sustainable development in higher education. Int. J. Sustain. Higher Educ. 2007, 8, 416-430. [CrossRef]

72. Rieckmann, M. Education for sustainable development goals. Learning objectives; UNESCO: Paris, France, 2017; ISBN 9231002090.

73. MIT Sustainability Office. Discover Living Labs. Available online: https://sustainability.mit.edu/living-labs (accessed on 16 March 2020). 
74. Simonsohn, U.; Simmons, J.P.; Nelson, L.D. Better P-curves: Making P-curve analysis more robust to errors, fraud, and ambitious P-hacking, a Reply to Ulrich and Miller (2015). J. Exp. Psychol. Gen. 2015, 144, 1146-1152. [CrossRef]

75. Yamada, Y. How to Crack Pre-registration: Toward Transparent and Open Science. Front. Psychol. 2018, 9 , 1831. [CrossRef]

76. De Wit, K. The Networked University: The structure, culture, and policy of universities in a changing environment. Tert. Educ. Manag. 2010, 16, 1-14. [CrossRef]

77. Selingo, J.J. The Networked University: Building Alliances for Innovation in Higher Education; Pearson: London, UK, 2017.

78. Holzer, B. Netzwerke; Transcript Verlag: Bielefeld, Germany, 2006; ISBN 9783839403655.

79. White, H.C. Network Switchings and Bayesian Forks: Reconstructing the Social and Behavioral Sciences. Soc. Res. 1995, 62, 1035-1063.

80. Tacke, V. Systeme und Netzwerke-oder: Was man an sozialen Netzwerken zu sehen bekommt, wenn man sie systemtheoretisch beschreibt. In Netzwerke und soziale Arbeit: Theorien, Methoden, Anwendungen; Fischer, J., Kosellek, T., Eds.; Beltz Juventa: Weinheim, Germany, 2013; pp. 143-162. ISBN 9783779928263.

81. Kleve, H. Die Wechselseitigkeit von Geben und Nehmen: Netzwerke als soziale Systeme. Systhema 2017, 31, 110-121.

82. Kleve, H. Reziprozität ermöglichen. Kontext 2017, 48, 353-367. [CrossRef]

83. Vangen, S.; Hayes, J.P.; Cornforth, C. Governing Cross-Sector, Inter-Organizational Collaborations. Pub. Manag. Rev. 2015, 17, 1237-1260. [CrossRef]

84. Luhmann, N. Die Gesellschaft der Gesellschaft; Suhrkamp: Frankfurt am Main, Germany, 1997; ISBN 351858247X.

85. Deutscher Bundestag. Bericht der Bundesregierung zur Bildung für nachhaltige Entwicklung. Unterrichtung durch die Bundesregierung (18. Wahlperiode); Bundestagsdrucksache 18/13665. 2017. Available online: https://www.bmbf.de/files/Drucksache_1813665_BT-Bericht\%20BNE.pdf (accessed on 20 March 2019).

86. Kiefhaber, E.; Spraul, K. Erfolgsfaktoren von Nachhaltigkeitsnetzwerken: Eine Sondierungsstudie für zukünftige Netzwerkforschung-Zusammenfassung der Ergebnisse für Studienteilnehmer; Technische Universitat Kaiserslautern: Kaiserslautern, Germant, 2016.

87. Spraul, K. Erfolgsfaktoren von Nachhaltigkeitsnetzwerken. In Proceedings of the 4. Symposium "Nachhaltigkeit in der Wissenschaft" (SISI), München, Germany, 17 July 2018.

88. Müller-Christ, G.; Liebscher, A.K. Advanced Training for Sustainability Change Agents-Insights and Experiences from a Seminar Series Using the Method of Systemic Constellations. In Integrative approaches to sustainable development al university level: Making the links; Leal Filho, W., Ed.; Springer: Heidelberg, Germany, 2015; pp. 451-466. ISBN 978-3-319-10689-2.

89. Denzler, W.; Schmitt, C.T. Digitalisierung und Nachhaltige Entwicklung an Hochschulen: Synergien und Spannungsfelder: Digitalisierung-Werkzeug und Thema im Hochschulnetzwerk HOCHN. Synergie Fachmagazin Digitalisierung Lehre 2019, 7, 30-33. [CrossRef]

90. Die HOCH-N-Nachhaltigkeitslandkarte. Available online: https://www.nachhaltige-hochschullandschaft.de (accessed on 10 January 2020).

91. Bassen, A.; Sassen, R.; de Haan, G.; Klußmann, C.; Niemann, A.; Gansel, E. Anwendung des hochschulspezifischen Nachhaltigkeitskodex —Ein Weg zur Nachhaltigkeitsberichterstattung an Hochschulen (Betaversion); BMBF-Projekt "Nachhaltigkeit an Hochschulen: Entwickeln-vernetzen-berichten (HOCH-N)": Hamburg, Germany, 2018.

92. Bormann, I.; Rieckmann, M.; Bauer, M.; Kummer, B.; Niedlich, S. Nachhaltigkeitsgovernance an Hochschulen (Betaversion); BMBF-Projekt "Nachhaltigkeit an Hochschulen: Entwickeln-vernetzen-berichten (HOCH-N)": Berlin, Germany, 2018; Available online: https://www.hochn.uni-hamburg.de/-downloads/handlungsfelder/ governance/hoch-n-leitfaden-nachhaltigkeitsgovernance-an-hochschulen.pdf (accessed on 9 January 2020).

93. Bauer, M.; Niedlich, S.; Rieckmann, M.; Bormann, I.; Jaeger, L. Interdependencies of Culture and Functions of Sustainability Governance at Higher Education Institutions. Sustainability 2020, 12, 2780. [CrossRef]

94. Bellina, L.; Tegeler, M.K.; Müller-Christ, G.; Potthast, T. Bildung für Nachhaltige Entwicklung (BNE) in der Hochschullehre (Betaversion); BMBF-Projekt "Nachhaltigkeit an Hochschulen: Entwickeln-vernetzen-berichten (HOCH-N)": Bremen, Germany, 2018; Available online: https://www.hochn.uni-hamburg.de/-downloads/ handlungsfelder/lehre/hoch-n-leitfaden-bne-in-der-hochschullehre.pdf (accessed on 9 January 2020).

95. Schopp, K.; Bornemann, M.; Potthast, T. The Whole-Institution Approach at the University of Tübingen: Sustainable Development Set in Practice. Sustainability 2020, 12, 861. [CrossRef] 
96. Kahle, J.; Jahn, S.; Lang, D.J.; Vogt, M.; Weber, C.F.; Lütke-Spatz, L.; Winkler, J. Nachhaltigkeit in der Hochschulforschung (Betaversion); BMBF-Projekt "Nachhaltigkeit an Hochschulen: Entwickeln-vernetzen-berichten (HOCH-N)": Lüneburg, Germany, 2018; Available online: https://www.hochn.uni-hamburg.de/-downloads/handlungsfelder/forschung/hoch-n-leitfadennachhaltigkeit-in-der-hochschulforschung.pdf (accessed on 9 January 2020).

97. Delakowitz, B.; Schön, E.; Bulcsu, A.; Günther, E.; Hüske, A.-K.; Roos, N.; Brauweiler, J.; Will, M.; Zenker-Hoffmann, A. Nachhaltigkeit im Hochschulbetrieb (Betaversion); BMBF-Projekt "Nachhaltigkeit an Hochschulen: Entwickeln-vernetzen-berichten (HOCH-N)": Zittau, Germany, 2018; Available online: https://www.hochn.uni-hamburg.de/-downloads/handlungsfelder/betrieb/hochn-leitfaden-nachhaltiger-hochschulbetrieb.pdf (accessed on 9 January 2020).

98. Roos, N.; Heinicke, X.; Guenther, E.; Guenther, T.W. The Role of Environmental Management Performance in Higher Education Institutions. Sustainability 2020, 12, 655. [CrossRef]

99. Nölting, B.; Dembski, N.; Kräusche, K.; Lehmann, K.; Molitor, H.; Pape, J.; Pfriem, A.; Reimann, J.; Skroblin, J.-H.; Walk, H. Transfer für nachhaltige Entwicklung an Hochschulen (Beta-Version); BMBF-Projekt "Nachhaltigkeit an Hochschulen: Entwickeln-vernetzen-berichten (HOCH-N)": Eberswalde, Germany, 2018; Available online: https://www.hochn.uni-hamburg.de/-downloads/handlungsfelder/transfer/hoch-nleitfaden-transfer-fuer-nachhaltige-entwicklung-an-hochschulen.pdf (accessed on 9 January 2020).

100. Nölting, B.; Molitor, H.; Reimann, J.; Skroblin, J.-H.; Dembski, N. Transfer for Sustainable Development at Higher Education Institutions-Untapped Potential for Education for Sustainable Development and for Societal Transformation. Sustainability 2020, 12, 2925. [CrossRef]

101. Giesenbauer, B. Veränderung durch Veränderung: Nachhaltige Entwicklung von Hochschulen im Huckepack der Digitalisierung. In Digitalisierung und Nachhaltigkeit: Chancen und Perspektiven für deutsche Hochschulen; Leal, W., Ed.; Springer: Heidelberg, Germany, 2020; in press.

102. Kruse, P. Next practice. In Erfolgreiches Management von Instabilität; GABAL: Offenbach, Germany, 2004.

103. Mehling, S.; Kolleck, N. Cross-Sector Collaboration in Higher Education Institutions (HEIs): A Critical Analysis of an Urban Sustainability Development Program. Sustainability 2019, 11, 4982. [CrossRef] 